\title{
Phytonanotechnology applications in modern agriculture
}

Meng Jiang ${ }^{1,2}$, Yue Song ${ }^{1,2}$, Mukesh Kumar Kanwar ${ }^{1,3,4}$, Golam Jalal Ahammed ${ }^{5}$, Shujun Shao ${ }^{1,3,4}$ and Jie Zhou ${ }^{1,3,4^{*}}$ (i)

\begin{abstract}
With the rapidly changing global climate, the agricultural systems are confronted with more unpredictable and harsh environmental conditions than before which lead to compromised food production. Thus, to ensure safer and sustainable crop production, the use of advanced nanotechnological approaches in plants (phytonanotechnology) is of great significance. In this review, we summarize recent advances in phytonanotechnology in agricultural systems that can assist to meet ever-growing demands of food sustainability. The application of phytonanotechnology can change traditional agricultural systems, allowing the target-specific delivery of biomolecules (such as nucleotides and proteins) and cater the organized release of agrochemicals (such as pesticides and fertilizers). An amended comprehension of the communications between crops and nanoparticles (NPs) can improve the production of crops by enhancing tolerance towards environmental stresses and optimizing the utilization of nutrients. Besides, approaches like nanoliposomes, nanoemulsions, edible coatings, and other kinds of NPs offer numerous selections in the postharvest preservation of crops for minimizing food spoilage and thus establishing phtonanotechnology as a sustainable tool to architect modern agricultural practices.
\end{abstract}

Keywords: Agricultural systems, Agrochemicals, Crop breeding, Growth and development, Nanotechnology, Postharvest preservation

\footnotetext{
*Correspondence: jie@zju.edu.cn

${ }^{3}$ Department of Horticulture, Zhejiang Provincial Key Laboratory

of Horticultural Plant Integrative Biology, Zhejiang University, Yuhangtang

Road 866, Hangzhou 310058, People's Republic of China

Full list of author information is available at the end of the article
} original author(s) and the source, provide a link to the Creative Commons licence, and indicate if changes were made. The images or other third party material in this article are included in the article's Creative Commons licence, unless indicated otherwise in a credit line to the material. If material is not included in the article's Creative Commons licence and your intended use is not permitted by statutory regulation or exceeds the permitted use, you will need to obtain permission directly from the copyright holder. To view a copy of this licence, visit http://creativecommons.org/licenses/by/4.0/. The Creative Commons Public Domain Dedication waiver (http://creativeco mmons.org/publicdomain/zero/1.0/) applies to the data made available in this article, unless otherwise stated in a credit line to the data. 


\section{Graphical Abstract}

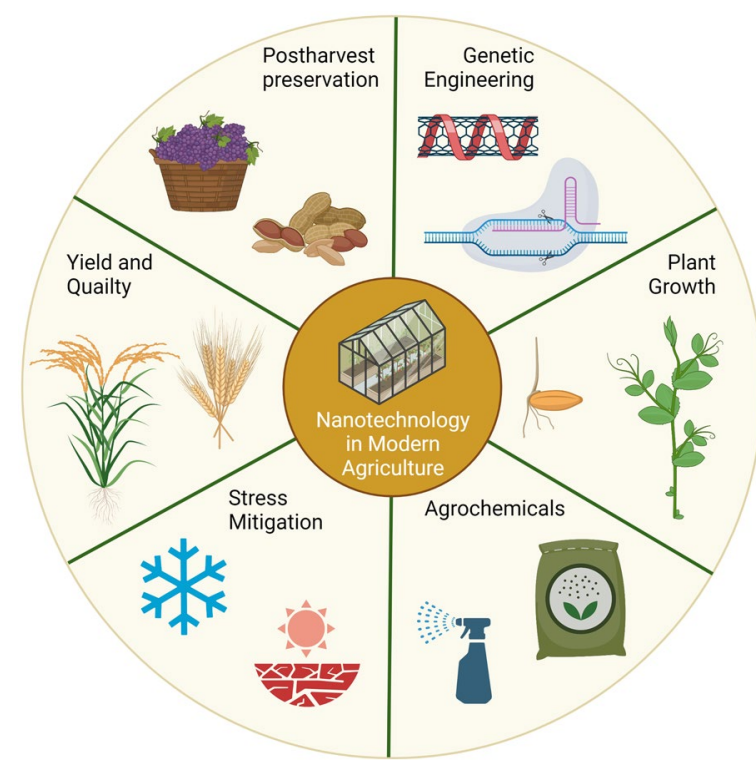

\section{Introduction}

Globally, the agricultural systems are being challenged with more and more unpredictable hazards. To safeguard sustainable agriculture and food production, the advanced agronomic application of nanotechnology in plants, termed phytonanotechnology, is of great significance [1]. Phytonanotechnology can improve agricultural production by minimizing relevant losses and increasing the efficiency of inputs, thus providing an important solution for keeping the feasible development of agrosystems and related sectors [2]. The prospective use of phytonanotechnology can bring a revolution in the agrosystems, through an enhancement in crop yields and productivity, while maintaining environmental sustainability, and ecological and economic stability [3]. The applications of phytonanotechnology in agricultural systems have helped the progress of 'intelligent' cropping and promoted conventional agricultural ways and practices, offering more environmentally efficient, and ingenious management [4]. Compared with the production materials used in traditional agricultural practices, phytonanotechnology offers many uses and scopes to be developed and understood.

Nanomaterials (NMs), have internal surface structures or external dimensions with three or two dimensions ranging from 1 to $100 \mathrm{~nm}$ [5]. NMs have special physicochemical characters, such as enhanced reactivity, atypical surface structure, and high surface-to-volume ratio which differ individually from those of their molecular counterparts [6]. NMs also offer multifunctional, programmed, self-regulated, target-specific, and timecontrolled abilities $[7,8]$. Owing to these special and versatile physicochemical characters, NMs are utilized gradually in a large number of agricultural practices. In detail, NMs participate in the targeted-specific transfer of proteins, nucleotides, or other phytoactive molecules that can genetically regulate and modify the metabolism in crops. As special carriers of agrochemicals, NMs can provide a larger specific surface area to herbicides, fertilizers, and pesticides and ensure their 'on-demand' release, whether it is for preventing pathogens, pests, and diseases, or nutritional needs [9]. Thus, NMs can promote controlled and targeted nutrient delivery, resulting in enhanced crop growth and development.

Numerous nanoparticles (NPs) have been widely utilized in phytonanotechnology, such as mesoporous silica NPs (MSNs), carbon nanotubes (CNTs), quantum dots (QDs), magnetic NPs (MNPs), metallic NPs, and metal oxide NPs [1]. MSNs include honeycomb-like porous structures with tunable outer particle diameter and tunable pore size in the nanometer range. They have hundreds of empty channels that are capable of absorbing or encapsulating different bioactive molecules or agrochemicals. Plasmids containing the Green Fluorescent Protein (GFP) gene can be delivered by MSNs, together entering into plant cells and finally triggering the expression of the target gene [10]. The enzyme or protein loaded by the system of MSNs can be used for genome modifications or biochemical analysis in plants [11]. This procedure avoids the delivery of the reformed characters to 


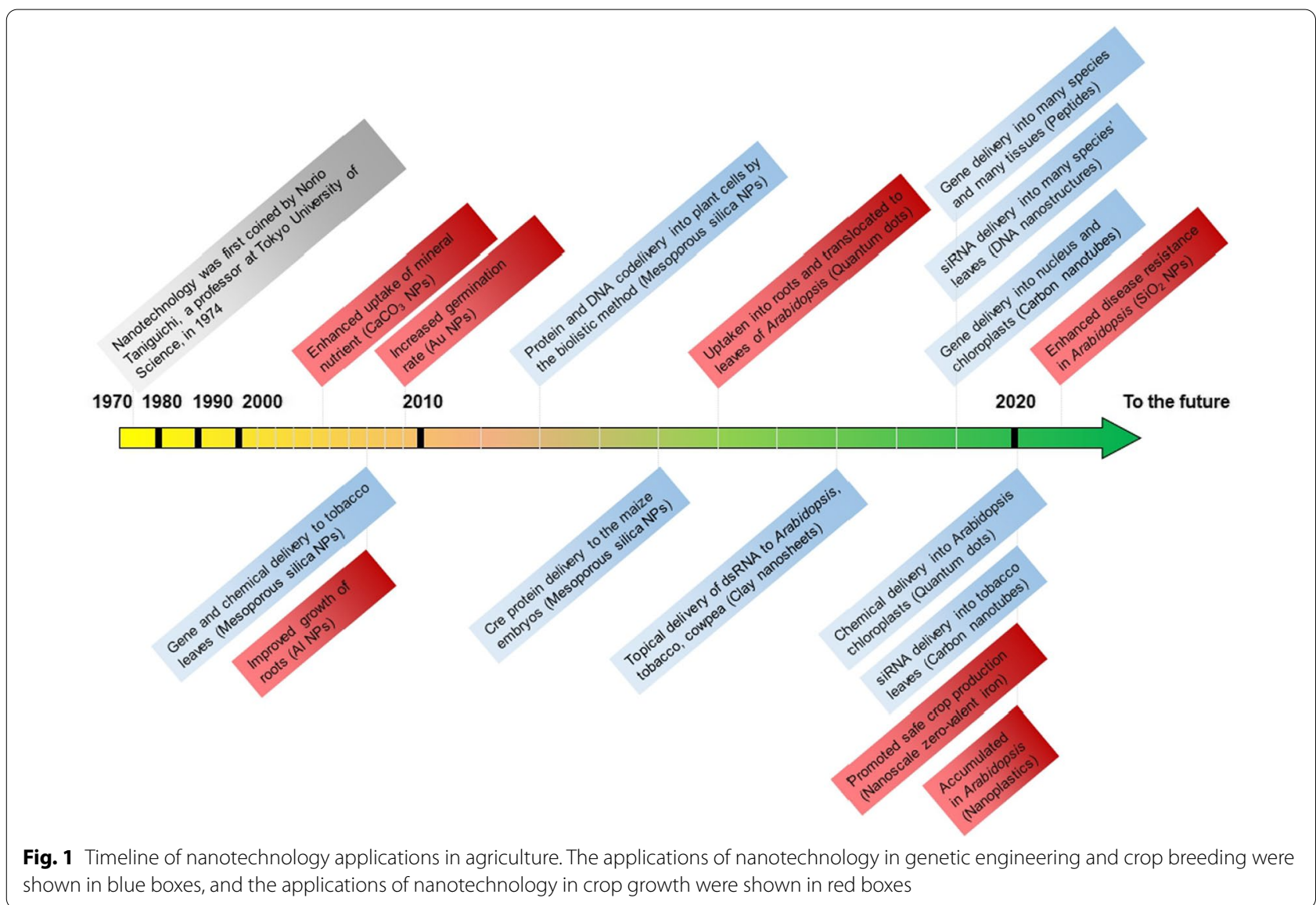

the next generations by integrating the transgene into the genome. CNTs are the allotropes of carbon that have cylindrical nanostructures with diameters between 1 and $50 \mathrm{~nm}$ [12]. They are classified as multi-walled nanotubes (MWNTs) and single-walled nanotubes (SWNTs). QDs are nanocrystals of semiconductor materials with diameters between 2 and $10 \mathrm{~nm}$ [13]. They can generate distinctive fluorescence that can be utilized for subcellular imaging or labeling. MNPs comprise different magnetic materials, e.g., Cobalt (Co), Nickel (Ni), Iron (Fe), and their derivative compounds. They are categorized as magnetic virus-like NPs (VNPs) [14], carbon-coated MNPs [15], and other magnetic NPs. They can be operated by using magnetic field gradients for targeted delivery. Au and Ag NPs are the most commonly used metallic NPs due to their better effectiveness in delivering biomolecules in crops [3]. Likewise, metallic oxide NPs of $\mathrm{ZnO}$, $\mathrm{CuO}, \mathrm{SiO}_{2}$, and $\mathrm{TiO}_{2} \mathrm{NPs}$, have also been broadly utilized as a delivery carrier in plants system due to the greater light absorption, catalytic, and electrical characteristics [16]. Numerous metallic and metallic oxides NPs have been applied in diverse crop management procedures including fertilization and crop protection [17]. Despite all the beneficial effects, attention must be paid to design safety principles to address the community dealing with the possible opposing influences of new NMs on the ecosystem (for example, application of NMs in a daily necessity product) [18].

Since the related research of phytonanotechnology in agricultural systems is exponentially increasing (Fig. 1), a complete review outlining the novel features of phytonanotechnology and its roles in crop development and other agricultural production is imperative. Thus, this review is aimed to provide the readers with complete mechanistic insights into the new paradigms of phytonanotechnology progressions in agriculture by investigating their roles in crop breeding, agrochemicals delivery, crop growth and development, and other allied functions to sustain and design a better agriculture system for the future (Fig. 2).

\section{Special properties and surface modifications of NPs}

The special properties of NPs make them more effective than ordinary materials, e.g., ions and molecules [19]. In a greenhouse experiment, crops were collected 


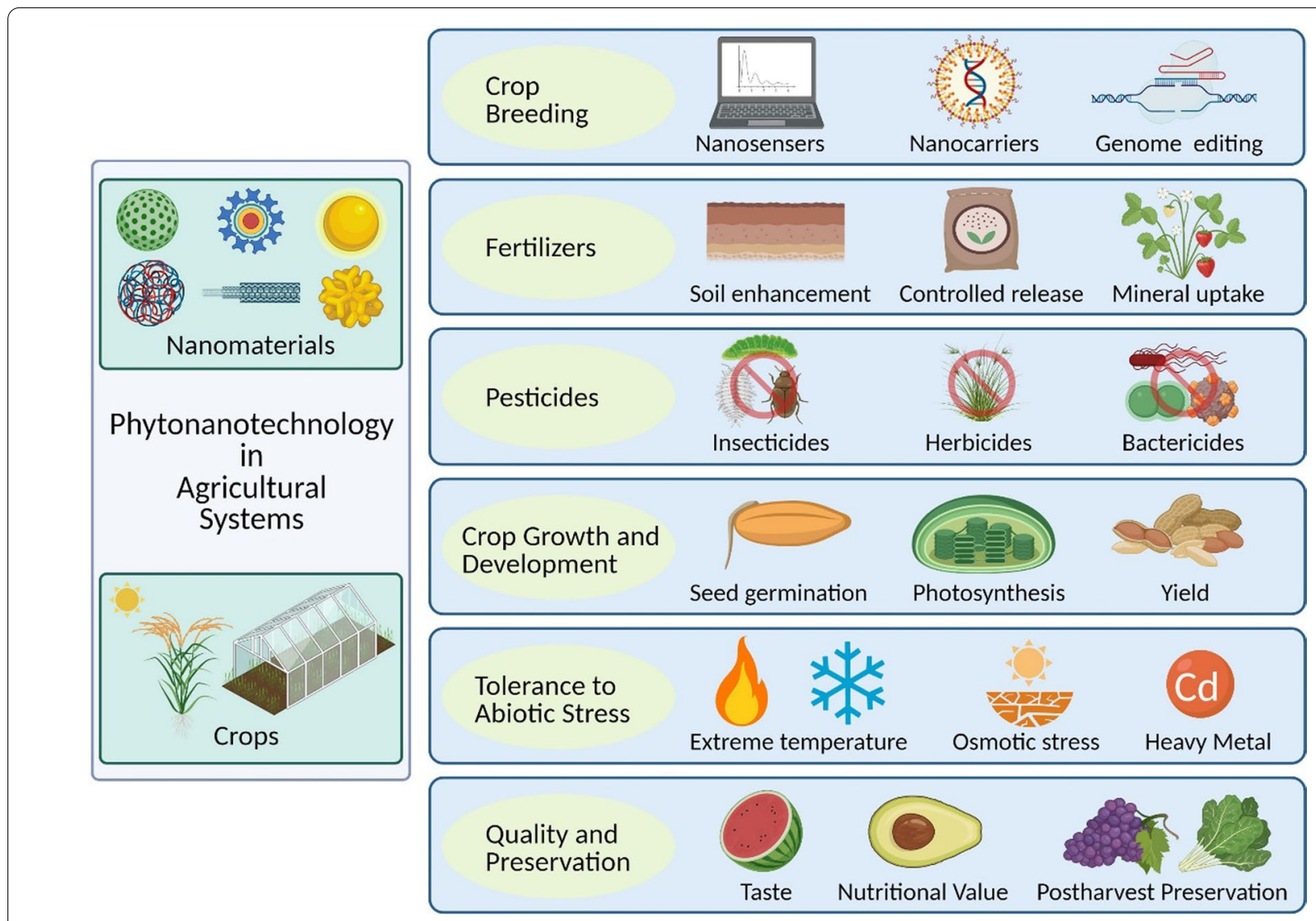

Fig. 2 Schematic illustrations of the applications of nanotechnology in agricultural systems

after growing for 80 days in soil modified with $\mathrm{CuSO}_{4}$ or $\mathrm{CuO}$ particles (bulk or nano) [20]. The $\mathrm{Cu}$-content in the root of nano- $\mathrm{CuO}$ treated crops was higher compared with bulk $\mathrm{CuO}, \mathrm{CuSO}_{4}$, or control. This indicated that nano- $\mathrm{CuO}$ was more easily absorbed by crops. Time-resolved tests were performed to analyze the physiological effects and the translocation of $\mathrm{Zn}$ in the common bean (Phaseolus vulgaris L.) [21]. The absorption spectroscopy of near-edge X-ray exhibited that $\mathrm{ZnSO}_{4}$ and $\mathrm{ZnO}(300 \mathrm{~nm})$ were more difficult to be absorbed by roots of bean than $\mathrm{ZnO}(40 \mathrm{~nm})$. It further demonstrated that $\mathrm{ZnO}$ in the nano state with smaller size was more easily absorbed by the crops. The highest level of $\mathrm{Zn}$ was found in $\mathrm{ZnO}$ NPs sprayed seedlings with $\sim 78$-fold in comparison to $\sim 27$-fold detected in $\mathrm{ZnSO}_{4}$ treated plants [22]. It is inferred that the higher $\mathrm{Zn}$ accumulation with $\mathrm{ZnO}$ NPs treatment was reasoned by the size property or better adhesion of the nano form compared to the ionic form, causing their more effective entry into the seedlings [23, 24]. The different transportation and accumulation features of silver $(\mathrm{Ag}) \mathrm{NPs}$ and $\mathrm{Ag}^{+}$were reported in rice (Oryza sativa L.) [25]. Ag NPs are translocated and assimilated more validly on the root surface compared to $\mathrm{Ag}^{+}$. Briefly, NPs are lightly transported in crop seedlings, so the optimum dosage of suitable size of NPs enhances their absorption in crops [26]. The activity, aggregation, catalytic charge, crystallinity, porosity, or redox potential can influence the uptake of NPs in crop seedlings. Furthermore, the high surface activity of NPs may speed up the metal component release [27]. The electrostatic attraction, hydrophilicity, lipophilicity, and physical adsorption of NPs, influence the accumulation [28]. For instance, the NPs with neutral or positive charges are more beneficial for agglomeration, but the NPs with negative charges are more beneficial for translocating in crops [29].

The absorption of NPs by crops can be enhanced by modifying their surface using numerous objects, such as iron, aminopropyl triethoxysilane, fluorescein isothiocyanate, natural organic matter [29], humic acid [30], polyvinylpyrrolidone [31], citrate [26], or polyethylene glycol [32]. In detail, the hydrophilic protective sheet makes NPs easily penetrable to crops [33], while the protein-encapsulated NPs are more stable in crops [34]. Nanocarriers allow the assimilation and carriage of nutrients such that nano-liposomes 


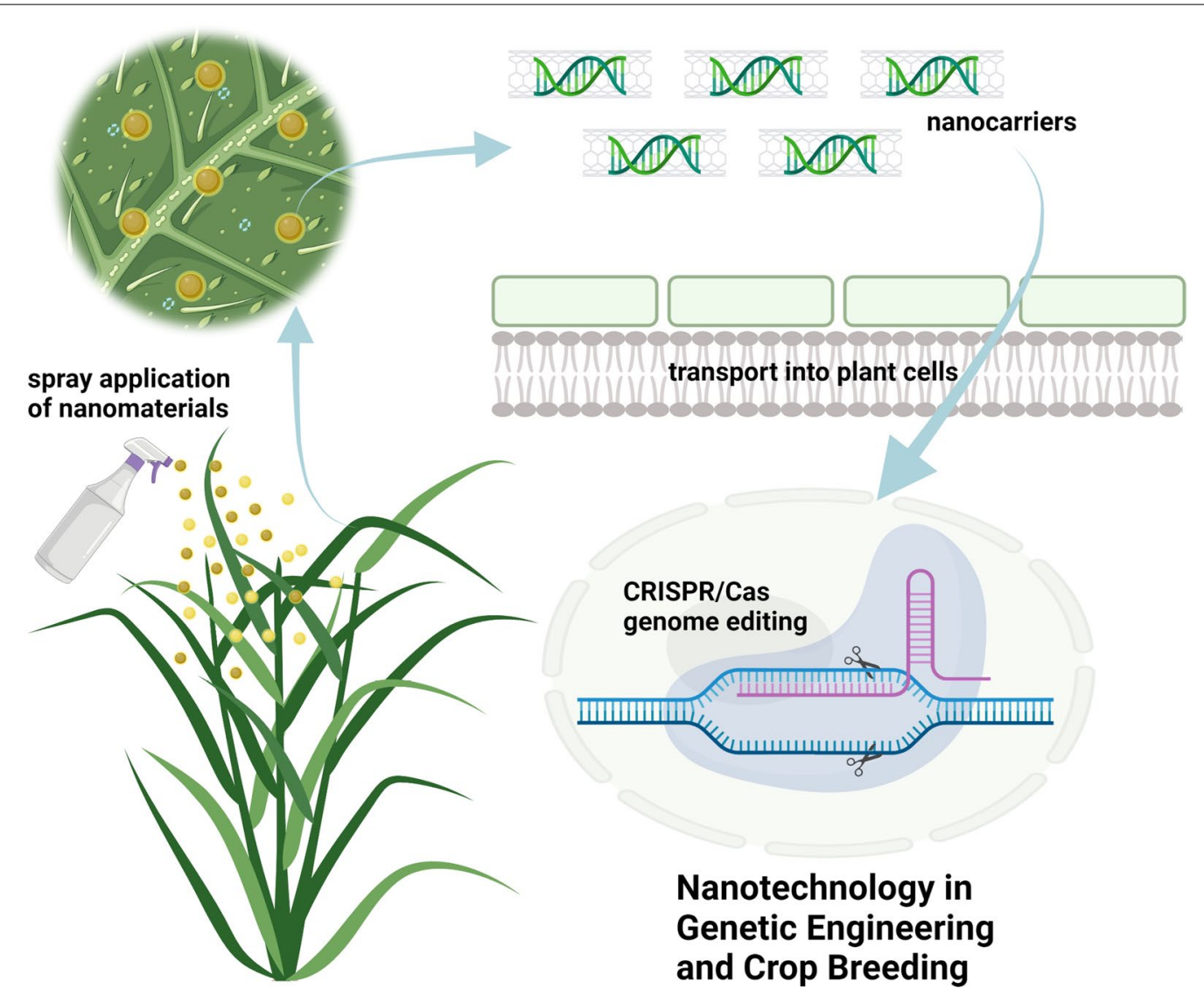

Fig. 3 Schematic diagram of the applications of nanotechnology in genetic engineering and crop breeding. Plasmids containing genes that encode Cas and the sgRNA are delivered into the plant cell through Agrobacterium-mediated transformation, protoplast transfection, particle bombardment, or even spray application with NMs. The CRISPR/Cas genome-editing system consists of the Cas endonuclease, which can site-specifically cleave double-stranded DNA, and an sgRNA that hybridizes to about 20 nucleotides of the target sequence

aid the transport and absorption of nutrients in various crops [35]. Organic macromolecules such as chitosan decrease the agglomeration of NPs, increase the stability of NPs, and allow them effortlessly enter into epidermal cells of leaves by modifying their chemical and physical characteristics [36]. Moreover, the NPs surface charge can be improved by coating, which contributes to their translocation [37]. Recent reports found that the material of surface coating can prevent the closure of stomata by decreasing the indiscriminate gathering of NPs, thus enhancing the absorption of NPs in crops [38]. Moreover, the utilization of functional groups and surfactants improves the bioavailability of NPs by increasing the NPs adhesion on the surface of leaves $[39,40]$. For instance, hydroxyapatite can be used to alter the surface of NPs to induce the absorption of leaves and decrease the aggregation of NPs [30].

\section{Nanotechnology in genetic engineering and crop breeding}

Crop breeding is acknowledged as a technology to improve the genetic characteristics of crops by generating high-yield and high-quality varieties [41]. Several conventional and molecular approaches have been used in crop breeding, including functional genomic tools, genetic selection, mutagenic breeding, physical maps, somaclonal variations, and whole-genome sequencebased approaches [42]. Nanotechnology is a new pioneering approach to improve the efficiency and accuracy of crop breeding (Fig. 3).

Nanobiotechnology improves the efficacy of crop breeding by delivering exogenous biochemicals or nucleotides into plant cells [43]. As transportation across the cell wall and limited size of inserted genetic material signify main barriers to transport of external molecules into crop cells, the combination of biotechnology and nanotechnology offers more chances as novel means of biomolecule transport into the cells through the cell wall 
[44]. Recently, a nanomaterial-mediated gene delivery system has been developed. High transformation efficiency is achieved without external physical or chemical means in plant cells, showing excellent applications in plant genetic engineering [45]. For example, the foremost application of delivering NMs into crops was carried by Torney et al. [10], where MSNs transported a target gene into the leaves of tobacco (Nicotiana benthamiana L.). $\mathrm{SiO}_{2}$ NPs have been developed to transport DNA to crops, e.g., tobacco and maize (Zea mays L.) with no adverse effects [46]. The technology of particle bombardment (or gene-gun) has been used to transform plants since the early 1980 s, using either tungsten or gold particles as DNA carriers [47]. The current system is adapted to allow NPs delivery, which most likely decreases the cell damage caused by microprojectile hits during the bombardment and thus improves the expression efficiency of the transgenes. The DNA-coated NPs are utilized as bullets in the gene-gun technology to bombard the tissues or cells to deliver the desired genes into the target crops [48]. Silicon carbide-participated plant transformation has been found to transfer the sequences or fragments of DNA in various calli [maize, tobacco, rice, soybean (Glycine max L.), and cotton (Gossypium hirsutum L.)] as an effective method [49]. The complex of MNPs and $\beta$-glucuronidase target gene was permeated to the pollens of cotton by magnetic force, with no negative effects on the viability of pollens. By pollinating with magnetofected pollens, the transgenic cotton plants were effectively selected and exogenous genetic information was steadily inherited into offspring achieved by selfing, successfully combined into the genome, and finally expressed [50]. The scaffolds of carbon nanotubes were applied to deliver linear or plasmid DNA, in cotton, tobacco, and wheat (Triticum aestivum L.) leaves, causing a strong transient expression of GFP [51, 52]. In addition to the above-mentioned DNA delivery, NPs are also used to deliver RNA into plant cells. Chitosan NPs-embedded small interfering RNA (siRNA) delivery systems have offered a novel strategy for crop improvement by permitting the unique dominance of the target pest as chitosan has the capability to validly bind with RNA and the ability to penetrate cell membranes [53]. The double-stranded RNAs (dsRNAs) carried on non-toxic and degradable clay nanosheets offer defense against cauliflower mosaic virus in leaves of tobacco [54]. The siRNA was transferred to tobacco seedlings constitutively expressing the GFP gene, resulting in a high percentage silencing of the target gene $[51,52]$. The carbon nanotubes-mediated platform realized effective RNA transfer into intact crop cells and protected RNA from nuclease degradation, enabling gene silencing of endogenous GFP in mutants [52].
Gene editing has been broadly used in crop science and has a great possibility of becoming the 'game changer' in crop breeding [55]. The system of clustered regularly interspaced short palindromic repeats (CRISPR)/ CRISPR-associated proteins (Cas), an RNA-based guard organization in prokaryotes, containing the Cas proteins and CRISPR repeat spacer arrays, has effectively been utilized for genome editing in crops [56]. CRISPR/ Cas genome editing has been useful in plants by traditional transformation and regeneration processes [55]. Delivery, low HDR efficiency, species dependence, and tissue culture and regeneration are the four main challenges in genome editing of crops. With the characteristics of small size, differently charged, high-throughput, and high tensile strength, NMs can enhance the specificity and efficiency of the CRISPR/Cas9 technique and minimize the possibility of off-target [57]. Contemporary developments in NMs-mediated particular transport of CRISPR/Cas9 single guide RNA (sgRNA) have started a novel period of genetic engineering. Moreover, MSNs have been applied to transport Cre recombinase in the immature embryos of maize as carriers, loading the sites of loxP site recombined into the chromosomal DNA. The loxP fragment was acceptably integrated after the delivery of modified MSNs in crop cells [11]. Cationic arginine gold NPs gathered Cas9En (E-tag)-ribonucleoproteins (RNP) transport of sgRNA in cultured cell lines offered high efficiency (around 30\%) of active nuclear or cytoplasmic gene editing, which can significantly promote the study of crops [58]. Although current nanotechnology has promoted the CRISPR/Cas9 technique in numerous crops, phytonanotechnology-based approaches are also demanded to overcome other difficulties to the genome editing of crops. There are still a lot of challenges, e.g., the range of plant species that can be genetically engineered, the forms of CRISPR/Cas genome editings that can be powerfully utilized in crops, the labor and time efforts essential for crop regeneration, and the low transport efficiency.

\section{Phytonanotechnology applications during the lifecycle of crops}

NMs, such as MSNs, Au NPs, $\mathrm{SiO}_{2} \mathrm{NPs}$, and Chitosan NPs are informed to enhance crop growth and development from the initial phases of seed germination to death or senescence in numerous crop species including soybean, rice, wheat, peanut (Arachis hypogaea L.), tomato (Solanum lycopersicum L.), potato (Solanum tuberosum L.), and onion (Allium cepa L.) [59]. NMs exhibit positive effects on crops by accelerating crop breeding, promoting seed germination, increasing photosynthesis, enhancing mineral uptake, and improving crop quality and yield [60]. The application of nanotechnology to the overall 


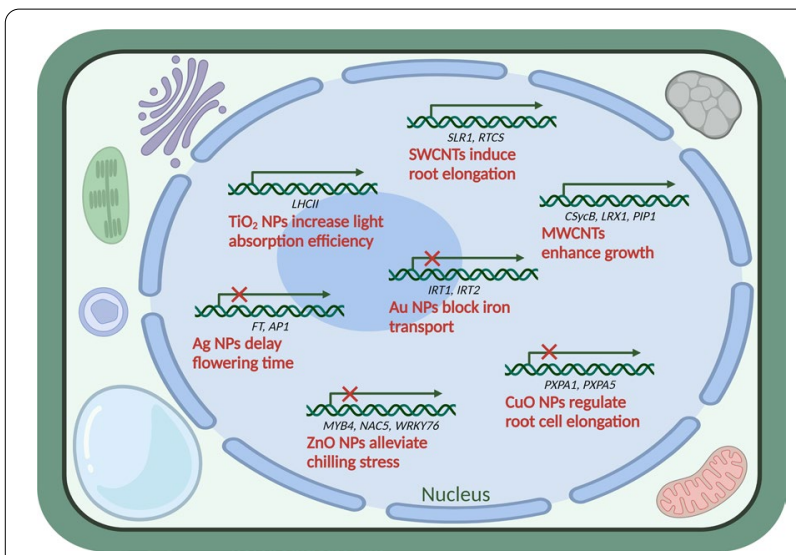

Fig. 4 Molecular mechanisms of nanomaterial actions in plant cells

growth and development process in plants is primarily dependent on the concentration, composition, size, and chemical and physical characteristics of NMs [61].

\section{Seed germination}

Seed germination is the first step and the most sensitive period in the life cycle of plants [62]. Numerous studies have revealed that the application of nanotechnology has beneficial influences on the germination of seeds. Studies have shown that NMs increase water absorption and utilization and have the ability to penetrate the seed coat, which can eventually improve seed germination and seedling growth by stimulating the enzyme system [6365]. For instance, the application of Zn NPs significantly promotes the germination of seeds in different crop species, e.g., onion, soybean, peanut, and wheat $[66,67]$. The use of metal oxide NPs such as $\mathrm{TiO}_{2}$ and $\mathrm{SiO}_{2} \mathrm{NPs}$ for seed treatment, was found to substantially improve seed germination in several crops [62]. Additionally, multiwalled carbon nanotubes (MWCNTs) applications also facilitate the germination of seeds in crops, such as soybean, maize, peanut, wheat, tomato, garlic (Allium sati$v u m$ L.), and barley (Hordeum vulgare L.) [68-70]. At the molecular level (Fig. 4), single-walled nanotubes (SWCNTs) upregulated the expression of SLR1 and RTCS genes in maize root tissues and increased root growth [71]. Although a large number of studies on the positive interactions between NMs and the germination of the seeds are being reported in crops, the underlying mechanisms of the superiority of NMs to traditional materials in seed germination remain hitherto unknown and need more comprehensive assessment.

\section{Photosynthesis}

Photosynthesis is a vital process for the growth and development of plants. It transforms light energy into chemical energy [72]. Thus, enhancing the efficiency of photosynthesis is critical for the better growth of crops [73]. It has been reported that NMs can enhance the system and enzyme activity of photosynthesis and the content of chlorophylls, which can eventually improve the overall plant growth [74]. At the physiological level, the nano-anatase $\mathrm{TiO}_{2}$ application enhances the rate of photosynthesis by stimulating the Rubisco enzyme activity, which could ultimately enhance the growth and development of crops [75]. The $\mathrm{SiO}_{2}$ NPs increase the capacity of photosynthesis via enhancing the photosynthetic metabolism and the carbonic anhydrase enzyme activity in crops [76]. The highest photosynthetic ability and an increase in chlorophyll content were found, when the seedlings were treated with $0.5 \mathrm{~g} / \mathrm{L}$ of $\mathrm{SiO}_{2} \mathrm{NPs}$ in wheat [77]. A comparable effect was also found by Rafique et al. [78], which showed that $60 \mathrm{mg} / \mathrm{kg}$ of $\mathrm{TiO}_{2} \mathrm{NPs}(<20 \mathrm{~nm})$ increased the content of chlorophylls by $32.3 \%$ compared to the control in wheat. At the molecular level (Fig. 4), $\mathrm{TiO}_{2}$ NPs induce the light-harvesting complex II (LHCII) gene in Arabidopsis thaliana, and finally enhance the chloroplast light absorption efficiency and thylakoid membrane LHCII content [79]. It has been reported that the Si NPs can stimulate the PsbY and HemD gene expression related to the biosynthesis of chlorophyll, thereby resulting in a higher photosystem II activity and an increased chlorophyll content $[80,81]$.

\section{Yield}

NPs can influence the yield of crops by changing the physiology and biochemistry of plants. In detail, $\mathrm{Fe}_{3} \mathrm{O}_{4}$ NPs maintain iron homeostasis, decrease lipid peroxidation, and induce ferritin content in maize [82]. Crops grown in the soil modified (hydrophilic or hydrophobic coating) or unmodified with nano- $\mathrm{TiO}_{2}$ for 2 months displayed that inorganic carbohydrate production, mineral uptake (P, Se, Mn, Fe, Mg, $\mathrm{Ca}$, and $\mathrm{Cu}$ ), chlorophyll, enzyme activity, and plant growth were enhanced significantly with the application of coated NPs [83]. Similarly, foliar applications of $\mathrm{Mn}, \mathrm{Fe}_{2} \mathrm{O}_{3}$, and Mo NPs also increase crop yield [28]. Moreover, various NPs have been used to enhance the dietary value and nutritional components of fruits or food grains. Foliar application of $\mathrm{Cu}$ NPs increases antioxidant enzyme activity, fruit firmness, and vitamin content, thus enhancing fruit freshness and quality in tomatoes [84]. At the molecular level (Fig. 4), Ag NPs affect the expression of VIN3, VRN2, $F R I$, and FLC in the vernalization pathway, and cause the down-regulation of key flowering control genes AP1 and $F T$, thereby delaying flowering [85]. The application of different NPs influences the quality and yield of crop seeds or fruits, which completely depends on the mode of treatment, property, size, and type of NPs used. Further 
investigation on dose-dependence, long-term exposure effects, as well as molecular studies such as metabolomics or proteomics can be an access device in determining the precise function of NPs on the quality and yield of seeds or fruits.

\section{Quality}

The significance of phytonanotechnology in crop-derived foods can be judged by evaluating their functions in the development of crop products in the fields of food quality, e.g., taste and nutritional value. The application of nanotechnology offers numerous ways to improve food taste. As compared to the larger materials which usually degrade substances over a longer time, the smaller NPs deliver favorable ways of enhancing the food bioavailability because the nearly subcellular size contributes to a higher level of bioavailability. Several metallic oxide NPs, e.g., $\mathrm{SiO}_{2}$ and $\mathrm{TiO}_{2}$, have been utilized as flow or color stuffs in food products [86]. Dekkers et al. [87] reported that $\mathrm{SiO}_{2}$ NPs were used as applied-NM to deliver flavors or fragrances into the food items. The novel technology of nano-encapsulation has been utilized widely to provide the balance of culinary and to increase flavor preservation and release [88]. The encapsulation of ferritin nanocages can increase the thermal stability and solubility of ferritin obtained rutin [89].

Large numbers of bioactive substances e.g., vitamins, proteins, carbohydrates, and lipids are more sensitive to the enzyme activity of the duodenum and stomach, and the high acidic environment. Nano-encapsulation permits the bioactive substances to assimilate readily in food products and allows them to struggle with such opposing conditions, which is difficult to attain in the non-capsulated forms because of the low water-solubility of the bioactive substances. The nano-emulsification, nano-structuration, and nanocomposite are the diverse tools that have been used to encapsulate the compounds in tiny shapes to more efficiently transport nutrients like antioxidants or proteins for health or nutritional assistance. Polymeric NPs are reported to be appropriate for bioactive substances encapsulation (such as vitamins or flavonoids) to transport and protect the bioactive substances for different purposes [90]. NPs-based tiny edible capsules are being made to develop the delivery of fragile micronutrients, vitamins, and medicines of the daily use food item and thus, offer an important advantage for human health [91].

\section{Postharvest preservation}

Food safety has become a worldwide issue because of increasing food demand and compromised crop yields resulting from climate change, soil degradation, and crop disease proliferation [92]. As per estimates, the global population will reach 9.6 billion by 2050, consequently, the demand for staple crops will increase by $60 \%$ [93]. Nanotechnology, such as nanofabrication and nanoencapsulation, can provide new added value solutions for the fortification of foods with bioactive and targeted controlled release in the gut to compensate for the food demand-supply objective [94].

A required packaging material must have moisture and gas permeability joint with biodegradability and strength [95]. As microcapsulization of vegetable oils have been used in postharvest preservation for a long time, nano-faciliated "active" and "smart" food packagings provide numerous advantages over conventional techniques with improved antimicrobial films, barrier properties, and mechanical strength [96]. Nanomaterials can also support food preservation aspects by being added directly into a food matrix or food contact materials such as packaging. The increasing application of nanotechnology offers numerous selections to extend the shelf-life of food for longer use. The use of nanotechnology in food preservation has revealed beneficial effects on diminishing spoilage. Nanoliposomes, nanoemulsions, edible coatings, and other different kinds of NPs have been widely used in the postharvest preservation of crop-derived foods [97].

Nanoliposomes have been certified to be valid in the targeted transport of antimicrobial compounds, nutraceuticals, nutrients, and vitamins owing to the small size with a larger area for surface contact [98]. It has been found that many factors are influencing the fusion of liposomes with bacterial cells, like bacterium surface $\mathrm{pH}$, temperature, divalent cations, and characteristics of the bacterial membrane. The delivery of negatively charged liposomes into the cells is promoted by nonspecific receptors, followed by particle recognition, adhesion and ultimately causing endocytosis [99]. The lipid composition of the bacterial membrane plays an important role in the fusion of liposomes to the bacterium [100].

Nanoemulsions are the mixtures of different immiscible liquids that are stabilized by a surfactant (e.g., modified starches, proteins, and lipids) with the average droplet size (20 to $200 \mathrm{~nm}$ ). The food-grade surfactants like lecithins, sugar esters, and polysorbates emulsifying agents utilized in postharvest preservation of crops play key roles in the stabilization of nanoemulsions through adequate responses to environmental stresses, such as enhanced loading capacity, steric hindrance, and the repulsive electrostatic interactions [101]. The characteristics of nanoemulsions cause them appropriate intermedia for transport of hydrophobic drugs, bioactive molecules, and nutraceuticals to encapsulate hydrophobic antioxidant ingredients [102]. 
Edible coatings have been reported to extend the shelf-life of perishable crop-derived foods, particularly vegetables or fruits. Edible coatings are traditionally thin materials applied with food-grade substances that are utilized on the surface of vegetables and fruits, therefore becoming a portion of crop-derived foods that stay on the outer surface during consumption and use [103]. The edible coatings contribute to postharvest preservation by controlling carbon dioxide and oxygen permeability, decreasing moisture loss, thus decreasing the rates of solute respiration, oxidation, and migration without compromising the quantity or quality of the crop-derived foods [104]. Edible coatings have good performance to play as a carrier vehicle for antimicrobial agents, micronutrients, flavoring compounds, colored pigments, and anti-browning mediums that assist in increasing valid period of crop-derived foods by preventing the survival of the pathogens on the outer surface of fresh vegetables and fruits during the food spoilage [105].

Nanocomposites have been widely applied for food packaging and preservation because of their antifungal or antibacterial properties [97]. The antimicrobial characteristic owned by Ag NPs has been widely used for postharvest preservation owing to their inactivation of food spoilage microorganisms. Special properties of $\mathrm{Ag}$ such as low volatility and stability at high temperatures and toxicity against various types of microbes make it a beneficial choice for application in postharvest preservation [106]. Nanocomposites applied with Ag NPs have been utilized to prolong the shelf-life of different kinds of crop-derived foods [107]. Mechanism of Ag NPs action is mediated by the release of $\mathrm{Ag}^{+}$in the following steps: adhesion to the cell surface of pathogens, disruption of the cell membrane of pathogens, damage of DNA, and cell death [108]. The primary mechanism of Ag NPs has been extracted in three routes: interruption of ATP production and DNA replication by the $\mathrm{Ag}^{+}$uptake, production of reactive oxygen species (ROS) by Ag NPs and $\mathrm{Ag}^{+}$ in the cells, and finally deterioration of the membrane of cells by Ag NPs [108]. Because of the excellent antimicrobial characteristic against microorganisms, $\mathrm{TiO}_{2} \mathrm{NPs}$ are extensively utilized in postharvest preservation [109]. Photocatalysis of $\mathrm{TiO}_{2}$ inactivates food spoilage bacteria by inducing the lipid peroxidation of phospholipids in microorganisms' cell membranes [110]. The antimicrobial mechanism of $\mathrm{TiO}_{2}$ NPs can be described in three routes; ROS production upon the activation by the UV and visible wavelength of light, oxidative stress and lipid peroxidation in cells, and the death of cells [111]. Despite these, more studies are needed to explore the underlying mechanism of the interactions between NPs and crops to increase the shelf-life and delay the ripening.

\section{Potential applications of phytonanotechnology in stress mitigation}

The change in climate around the world results in extreme temperature, salinity, drought, and various environmental pollution with excessive heavy metals are thought as one of the main reasons that influence the growth and development of crops [112, 113] (Table 1). The augmented adaptation of crops needs a many-sided approach, e.g., regulation of hormones, activation of plant enzymatic system, expression of stress genes, avoidance of water deficit stress, and control of the heavy metal translocation and uptake [114, 115]. Advances in NMs can raise the production of crops in the present opposing environment $[59,116]$. The studies below display that nanotechnology can alleviate the bad influences of abiotic stress.

\section{Extreme temperatures}

Plants suffer due to extreme temperatures (heat or cold stress) as their growth, development, and productivity are generally compromised under such conditions [153]. Extreme temperature stresses cause slow growth, low germination rate, decreased photosynthetic rate, denaturation of biomolecules, and disintegration of membrane lipids in crops [154]. NPs can alleviate these bad effects primarily by reducing oxidative stress and the overproduction of $\mathrm{ROS}$ [155]. $\mathrm{TiO}_{2} \mathrm{NPs}$ decreased the energy dissipation of nonregulated PS II and increased the energy dissipation of regulated photosystem II (PS II) during the high-temperature stress in tomato seedlings and finally stimulated the photosynthesis system [119]. The application of $\mathrm{TiO}_{2} \mathrm{NPs}$ not only prevented membrane damage under cold stress but also alleviated oxidative stress in chickpea (Cicer arietinum L.) [156]. NPs promoted crop growth under extreme temperature stress by altering various processes at the physiological, biochemical, and molecular levels (Fig. 4). Moreover, $\mathrm{TiO}_{2} \mathrm{NPs}$ treatment increased the crop tolerance to cold stress via maintaining the stability of carotenoid and chlorophyll accumulations, inducing the activities of ascorbate peroxidase and catalase [157], and enhancing gene expression of chlorophyll- and Rubisco-binding proteins [125]. Khodakovkaya et al. [158] showed that MWCNTs triggered the response of stresses in crops leading to the upregulation in the expression of different stresses-associated genes including HSP90. Similarly, Zhao et al. [118] found that $\mathrm{CeO}_{2}$ NPs upregulated the expression of HSP7O and diminishes the content of $\mathrm{H}_{2} \mathrm{O}_{2}$. The use of $\mathrm{ZnO}$ NPs increased the chilling stress-triggered gene expression by modulating the cold response transcription factors in leaves [126]. 
Table 1 Ameliorative effects of NMs on abiotic stress in crops

\begin{tabular}{|c|c|c|c|c|}
\hline Abiotic stress & Nanomaterials (size) & Plant species & Ameliorative effects & References \\
\hline \multirow[t]{6}{*}{ Heat } & MWCNTs (10-35 nm) & Tomato (Solanum lycopersicum L.) & $\begin{array}{l}\text { Upregulated the expression of vari- } \\
\text { ous stress-related genes including } \\
\text { HSP90 }\end{array}$ & Khodakovskaya et al. [117] \\
\hline & $\mathrm{CeO}_{2} \mathrm{NPs}(\sim 10 \mathrm{~nm})$ & Maize (Zea mays L.) & $\begin{array}{l}\text { Decreased production of hydrogen } \\
\text { peroxide }\left(\mathrm{H}_{2} \mathrm{O}_{2}\right) \text { and upregulation } \\
\text { of } \mathrm{HSP} 70\end{array}$ & Zhao et al. [118] \\
\hline & $\mathrm{TiO}_{2} \mathrm{NPs}(\sim 16 \mathrm{~nm})$ & Tomato (S. lycopersicum L.) & $\begin{array}{l}\text { Enhanced photosynthesis, } \\
\text { regulated energy dissipation, and } \\
\text { induced stomatal opening }\end{array}$ & Qi et al. [119] \\
\hline & Ag NPs (10-20 nm) & Wheat (Triticum aestivum L.) & $\begin{array}{l}\text { Protected plants against heat } \\
\text { stress and improved plant growth } \\
\text { significantly }\end{array}$ & lqbal et al. [120] \\
\hline & Ag NPs (15-30 nm) & Wheat (T. aestivum L.) & $\begin{array}{l}\text { Alleviated the harmful effects of } \\
\text { salinity stress }\end{array}$ & Abou-Zeid and Ismail [121] \\
\hline & Se NPs $(10-40 \mathrm{~nm})$ & Tomato (S. lycopersicum L.) & $\begin{array}{l}\text { Increased chlorophyll content, } \\
\text { hydration of plants, and growth }\end{array}$ & Djanaguiraman et al. [122] \\
\hline \multirow[t]{4}{*}{ Cold } & $\mathrm{SiO}_{2} \mathrm{NPs}(10-15 \mathrm{~nm})$ & $\begin{array}{l}\text { Wheatgrass (Agropyron elongatum } \\
\text { L.) }\end{array}$ & $\begin{array}{l}\text { Overcame seed dormancy, } \\
\text { enhanced seed germination and } \\
\text { seedling weight }\end{array}$ & Azimi et al. [123] \\
\hline & $\mathrm{Na}_{2} \mathrm{SeO}_{4} \mathrm{NPs}(20-35 \mathrm{~nm})$ & Tomato (S. lycopersicum L.) & $\begin{array}{l}\text { Improved plant growth, chlo- } \\
\text { rophyll, and leaf-relative water } \\
\text { contents }\end{array}$ & Haghighi et al. [124] \\
\hline & $\mathrm{TiO}_{2} \mathrm{NPs}(\sim 20 \mathrm{~nm})$ & Chickpea (Cicer arietinum L.) & $\begin{array}{l}\text { Enhanced expression of Rubisco- } \\
\text { and chlorophyll-binding protein } \\
\text { genes }\end{array}$ & Hasanpour et al. [125] \\
\hline & ZnO NPs ( 30 nm) & Rice (Oryza sativa L.) & $\begin{array}{l}\text { Alleviated chilling stress by regulat- } \\
\text { ing the chilling response transcrip- } \\
\text { tion factors }\end{array}$ & Song et al. [126 \\
\hline \multirow[t]{12}{*}{ Salinity } & $\mathrm{SiO}_{2} \mathrm{NPs}(\sim 20 \mathrm{~nm})$ & Tomato (S. lycopersicum L.) & $\begin{array}{l}\text { Alleviated the effect of salinity } \\
\text { on fresh weight, chlorophyll, and } \\
\text { photosynthetic rate }\end{array}$ & Haghighi and Pourkhaloee [127] \\
\hline & $\mathrm{SiO}_{2} \mathrm{NPs}(\sim 12 \mathrm{~nm})$ & Squash (Cucurbita pepo L.) & $\begin{array}{l}\text { Reduced levels of malondialde- } \\
\text { hyde (MDA), } \mathrm{H}_{2} \mathrm{O}_{2} \text {, and electrolyte } \\
\text { leakage }\end{array}$ & Siddiqui et al. [76] \\
\hline & $\mathrm{SiO}_{2} \mathrm{NPs}(\sim 20 \mathrm{~nm})$ & Tomato (S. lycopersicum L.) & $\begin{array}{l}\text { Suppressed the effect of salinity on } \\
\text { germination rate, root length, and } \\
\text { fresh weight }\end{array}$ & Almutairi [128] \\
\hline & Chitosan NPs ( 38 nm) & Maize (Z. mays L.) & $\begin{array}{l}\text { Alleviated the harmful effects of } \\
\text { salinity stress }\end{array}$ & Bruna et al. [129] \\
\hline & MWCNTs (30-100 nm) & Cabbage (Brassica oleracea L.) & $\begin{array}{l}\text { Alleviated the harmful effects of } \\
\text { salinity stress }\end{array}$ & Martinez-Ballesta et al. [130] \\
\hline & ZnO NPs ( 20 nm) & Sunflower (Helianthus annuus L.) & $\begin{array}{l}\text { Increased net } \mathrm{CO}_{2} \text { assimilation rate, } \\
\text { sub-stomatal } \mathrm{CO}_{2} \text { content, and } \mathrm{Fv} / \\
\mathrm{Fm} \text { ratio }\end{array}$ & Torabian et al. [131] \\
\hline & $\mathrm{Fe}_{2} \mathrm{O}_{3} \mathrm{NPs}(\sim 50 \mathrm{~nm})$ & Peppermint (Mentha piperita L.) & $\begin{array}{l}\text { Increased leaf dry weight, phos- } \\
\text { phorus, potassium, iron, zinc, and } \\
\text { calcium contents }\end{array}$ & Askary et al. [132] \\
\hline & $\mathrm{Fe}_{2} \mathrm{O}_{3} \mathrm{NPs}(\sim 20 \mathrm{~nm})$ & Wheat (T. aestivum L.) & $\begin{array}{l}\text { Improved the growth of both root } \\
\text { and shoot }\end{array}$ & Fathi et al. [133] \\
\hline & ZnO NPs ( 20 nm) & Wheat (T. aestivum L.) & $\begin{array}{l}\text { Improved the growth of both root } \\
\text { and shoot }\end{array}$ & Fathi et al. [133] \\
\hline & $\mathrm{SiO}_{2} \mathrm{NPs}(\sim 10 \mathrm{~nm})$ & Cucumber (Cucumis sativus L.) & $\begin{array}{l}\text { Increased plant germination and } \\
\text { growth characteristics }\end{array}$ & Alsaeedi et al. [134] \\
\hline & $\mathrm{SiO}_{2} \mathrm{NPs}(20-30 \mathrm{~nm})$ & Soybean (Glycine max L.) & $\begin{array}{l}\text { Reduced oxidative damage due } \\
\text { to expression of antioxidative } \\
\text { enzymes }\end{array}$ & $\begin{array}{l}\text { Farhangi-Abriz and Torabian } \\
\text { [135] }\end{array}$ \\
\hline & Chitosan NPs $(\sim 25 \mathrm{~nm})$ & Tomato (S. Iycopersicum L.) & $\begin{array}{l}\text { Alleviated the harmful effects of } \\
\text { salinity stress }\end{array}$ & $\begin{array}{l}\text { Hernandez-Hernandez et al. } \\
\text { [136] }\end{array}$ \\
\hline
\end{tabular}


Table 1 (continued)

\begin{tabular}{|c|c|c|c|c|}
\hline Abiotic stress & Nanomaterials (size) & Plant species & Ameliorative effects & References \\
\hline & $\mathrm{CeO}_{2} \mathrm{NPs}(\sim 8.5 \mathrm{~nm})$ & Cotton (Gossypium hirsutum L.) & $\begin{array}{l}\text { Modulated a-amylase activities and } \\
\text { ROS homeostasis }\end{array}$ & Khan et al. [137] \\
\hline & $\mathrm{CeO}_{2} \mathrm{NPs}(\sim 8 \mathrm{~nm})$ & Rapeseed (Brassica napus L.) & $\begin{array}{l}\text { Enabled better ability to maintain } \\
\text { cytosolic } \mathrm{K}^{+} / \mathrm{Na}^{+} \text {ratio }\end{array}$ & Liu et al. [138] \\
\hline \multirow[t]{7}{*}{ Drought } & $\mathrm{TiO}_{2} \mathrm{NPs}(\sim 20 \mathrm{~nm})$ & Wheat (T. aestivum L.) & $\begin{array}{l}\text { Increased growth, yield, gluten, and } \\
\text { starch content }\end{array}$ & Jaberzadeh et al. [139] \\
\hline & ZnO NPs ( 20 nm) & Soybean (G. max L.) & $\begin{array}{l}\text { Increased germination percentage } \\
\text { and rate, decrease in fresh and dry } \\
\text { weights }\end{array}$ & Sedghi et al. [67] \\
\hline & $\mathrm{Fe}_{2} \mathrm{O}_{3} \mathrm{NPs}(20-100 \mathrm{~nm})$ & Sunflower (H. annuus L.) & $\begin{array}{l}\text { Counteracted drought stress with } \\
\text { no effect on proline and total } \\
\text { amino acids }\end{array}$ & Martinez-Fernandez et al. [140] \\
\hline & $\mathrm{TiO}_{2}$ NPs $(10-25$ nm) & Lin seed (Linum usitatissimum L.) & $\begin{array}{l}\text { Enhanced chlorophyll and carot- } \\
\text { enoid content, decreased } \mathrm{H}_{2} \mathrm{O}_{2} \text { and } \\
\text { MDA contents }\end{array}$ & Aghdam et al. [141] \\
\hline & MWCNTs (20-30 nm) & Barley (Hordeum vulgare L.) & $\begin{array}{l}\text { Boosted seed water absorption and } \\
\text { increased seedling water content }\end{array}$ & Karami and Sepehri [142] \\
\hline & $\mathrm{CeO}_{2} \mathrm{NPs}(6-24 \mathrm{~nm})$ & Soybean (G. max L.) & $\begin{array}{l}\text { Enhanced growth, development, } \\
\text { and yield }\end{array}$ & Cao et al. [143] \\
\hline & Fe NPs (40-53 nm) & Strawberry (Fragaria ananassa L.) & $\begin{array}{l}\text { Enhanced acclimation and resist- } \\
\text { ance of plants to drought }\end{array}$ & Mozafari et al. [144] \\
\hline \multirow[t]{9}{*}{ Heavy metal } & $\mathrm{Fe}_{3} \mathrm{O}_{4} \mathrm{NPS}(\sim 20 \mathrm{~nm})$ & Rice (O. sativa L.) & $\begin{array}{l}\text { Reduced As transport from the root } \\
\text { to the shoot }\end{array}$ & Huang et al.[145] \\
\hline & Si NPs ( 50 nm) & Wheat (T. aestivum L.) & $\begin{array}{l}\text { Alleviated } \mathrm{Cd} \text { toxicity by reduc- } \\
\text { ing } \mathrm{Cd}^{2+} \text { uptake and enhancing } \\
\text { antioxidative capacity }\end{array}$ & Ali et al. [146] \\
\hline & CuO NPs (9-22 nm) & Rice (O. sativa L.) & $\begin{array}{l}\text { Reduced total As by } 23 \% \text { and } 45 \% \\
\text { in roots and shoots }\end{array}$ & Wang et al. [147] \\
\hline & ZnO NPs (30-40 nm) & Rice (O. sativa L.) & $\begin{array}{l}\text { Improved plant growth and allevi- } \\
\text { ated the toxic effects of } \mathrm{Cd}\end{array}$ & Zhang et al. [148] \\
\hline & $\mathrm{SiO}_{2} \mathrm{NPs}(\sim 100 \mathrm{~nm})$ & Rice (O. sativa L.) & $\begin{array}{l}\text { Inhibited As uptake into rice sus- } \\
\text { pension cells via improving pectin } \\
\text { synthesis }\end{array}$ & Cui et al. [149] \\
\hline & $\mathrm{TiO}_{2} \mathrm{NPs}(36-140 \mathrm{~nm})$ & Rice (O. sativa L.) & $\begin{array}{l}\text { Reduced As toxicity and reduced } \\
\text { As bioaccumulation in rice seed- } \\
\text { lings by } 40-90 \%\end{array}$ & Wu et al.[150] \\
\hline & Au NPs ( $40 \mathrm{~nm})$ & Rice (O. sativa L.) & $\begin{array}{l}\text { Suppressed Cd uptake and allevi- } \\
\text { ated Cd toxicity }\end{array}$ & Jiang et al. [151] \\
\hline & ZnO NPs (20-40 nm) & Rice (O. sativa L.) & $\begin{array}{l}\text { Modulated early growth and } \\
\text { enhanced physio-biochemical and } \\
\text { metabolic profiles }\end{array}$ & Li et al. [65] \\
\hline & ZnO NPs (20-30 nm) & Rice (O. sativa L.) & $\begin{array}{l}\text { Alleviated the As toxicity and } \\
\text { decreased the accumulation of As }\end{array}$ & Yan et al. $[45,152]$ \\
\hline
\end{tabular}

\section{Osmotic stress}

NPs improve the tolerance of crops to osmotic stresses, e.g., high salinity and drought. The stress caused by over-accumulation of anions of $\mathrm{SO}_{4}{ }^{2-}$ and $\mathrm{Cl}^{-}$as well as cations of $\mathrm{Na}^{+}, \mathrm{Mg}^{2+}$, and $\mathrm{Ca}^{2+}$, commonly known as salinity, limits the production of crops in about onefifth of the cultivated land around the world [159]. NPs can alleviate the damage caused by high salinity stress to crops in many ways like by restoring the damage to the photosynthesis system and altering the accumulation of metals in crops. Siddiqui and Al-Whaibi [160] found that $\mathrm{SiO}_{2}$ NPs treatment increased plant dry weight, seed germination, proline accumulation, and chlorophyll content in squash and tomato plants under $\mathrm{NaCl}$ stress. Foliar application of $\mathrm{FeSO}_{4}$ NPs not only induced shoot dry weight, chlorophyll content, leaf area, maximum photochemical efficiency of photosystem II ( Fv/Fm), and net $\mathrm{CO}_{2}$ assimilation rate, but also reduced $\mathrm{Na}$ content in 
leaves of sunflower cultivars under salinity stress [161]. Recent studies on the use of chitosan NPs in tomato [136] and maize [129], MWCNTs in broccoli [130], and Ag NPs in wheat seedlings [121], further reveal the mitigating effect of NPs on high salinity stress. $\mathrm{CeO}_{2}$ NPs enhance salt tolerance by enabling better ability to maintain cytosolic $\mathrm{K}^{+} / \mathrm{Na}^{+}$ratio in cotton [138]. Nanoceria seed priming improves salt tolerance by modulating $\alpha$-amylase activities and ROS homeostasis in rapeseed [137].

The increasing scarcity of agricultural water has adversely affected agricultural production and destroyed the green crops in the semiarid and arid areas of the world [162]. Huge achievements have been attained to alleviate the bad influences of drought on crop seedlings by using phytonanotechnology in different aspects, such as restoring the plant growth damage caused by severe drought, enhancing water accumulation, and inducing water absorption of seed in crops. Sodium nitroprusside (SN) NPs and MWCNTs enhanced the tolerance to drought stress by increasing seedling water content and boosting seed water absorption in barley [142]. The use of $\mathrm{CeO}_{2}$ NPs [143] and micronutrient NPs [163] enhanced crop growth and development exposed to drought stress in soybean.

\section{Heavy metals}

Rapid urbanization and industrialization in recent decades have greatly contributed to soil pollution. Heavy metals, e.g., Arsenic (As), Mercury (Hg), Chromium (Cr), Cadmium $(\mathrm{Cd})$, and Lead $(\mathrm{Pb})$, are among the chief pollutants in soil [164]. Phytonanotechnology, is one of the effective ways to remediate or detoxify dangerous pollutants like toxic heavy metals (HMs) by different routes, such as by decreasing the overproduction of ROS and oxidative stress caused by HMs, reducing their accumulation in food crops, and inhibiting heavy metals-triggered expression of the metal(s) transporter-associated genes in food crops. For example, it was reported that the use of $2.5 \mathrm{mM}$ Si NPs can greatly enhance the tolerance to $\mathrm{Cd}$ stress in rice seedlings by minimizing the excessive ROS caused by Cd [165]. Wang et al. [166] also found that Si NPs have a benefit over conventional fertilizers in decreasing the accumulation of $\mathrm{HMs}$ in plants. The $\mathrm{ZnO}$ NPs reduced the Cd uptake in wheat [167] and decreased the accumulation of As in rice plants [152]. Jiang et al. [151] reported that the application of Au NPs synthesized with melatonin (Mel-Au NPs) alleviated Cd stress in rice, by reducing $\mathrm{Cd}$-generated oxidative stresses and preventing the uptake of $\mathrm{Cd}$. Moreover, Mel-Au NPs treatment inhibited the expression of metal transporter-related genes under $\mathrm{Cd}$ stress in rice roots. $\mathrm{ZnO}$ NPs-based seed priming modulates early growth and enhances physio-biochemical and metabolic profiles of fragrant rice under Cd toxicity [65].

However, the overuse of NPs may pollute the environment (soil and water) by dispersing from agricultural fields or remediation activities, e.g. fertilizers and pesticides [168]. The high concentration of NPs also harms the growth and development of crops [169]. High levels of NPs have significant effects on gene expression and can induce oxidative stress, resulting in membrane damage, electrolyte leakage, and decreased photosynthetic pigment content in crops [170]. For example, $1 \mathrm{~g} / \mathrm{kg} \mathrm{ZnO}$ or $\mathrm{CuO}$ NPs may badly affect the function and structure of photosynthetic machinery in crops and limit the development of roots and shoots [171, 172]. The appropriate dose of NPs is important for the application of phytonanotechnology.

\section{Nanotechnology in agrochemicals for crop and disease management}

Agrochemicals are chemical products that comprise fertilizers, pesticides (insecticides, herbicides, and bactericides), and plant growth regulators used in agricultural practices to improve crop yield and quality [173]. Nanotechnology is widely utilized in agrochemicals, and the details of nanotechnology used in agrochemicals are discussed below.

\section{Nanotechnology in fertilizers}

Fertilizers are necessary for enhancing soil fertility and crop productivity [174]. The environmental restrictions and the incomplete use of nutrients related to the utilization of traditional fertilizers are still big issues for accomplishing sustainability in agricultural systems [175]. Additionally, nanofertilizers can be the best choice to conquer problems like eutrophication and enhance nutrient use efficiency in agriculture [176, 177]. Based on the functions, nanofertilizers can be classified as nanocomposite fertilizers, controlled-release fertilizers, or controlled loss fertilizers as combined nano-device to provide different macro- and micro-nutrients with ideal characteristics [178].

The application of nano-composite fertilizers for the controlled release can improve soil health, promote the crop uptake process, regulate rhizosphere microorganisms, and stimulate the productivity and growth of crops [179]. The absorption of NPs not only enhances the content of absorbed elements, but also increases the content of other elements in crops. For example, a study conducted on sandy loam soil-cultivated cucumber seedlings showed that $0.5 \mathrm{~g} / \mathrm{kg}$ of $\mathrm{TiO}_{2}$ NPs exposure produced approximately $34 \%$ more $\mathrm{P}$ content and $35 \%$ more $\mathrm{K}$ content than those in the control [180]. Similarly, the 
influence of $\mathrm{ZnO}$ NPs on mineral uptake in cucumber seedlings indicated that $\mathrm{ZnO}$ NPs greatly induced uptake of minerals [181]. The uptake of $\mathrm{Al}$ in seedlings of lettuce treated by $10 \mathrm{mg} / \mathrm{L} \mathrm{Fe} / \mathrm{Fe}_{2} \mathrm{O}_{3}$ NPs was increased [182]. A greatly induced absorption of $\mathrm{Fe}, \mathrm{Zn}, \mathrm{S}$, and $\mathrm{Al}$, and a decreased uptake of $\mathrm{P}, \mathrm{Mn}$, and $\mathrm{Mg}$ were found in lettuce seedlings when treated with 10 or $20 \mathrm{mg} / \mathrm{L} \mathrm{Cu} / \mathrm{CuO}$ NPs [182]. Similarly, $1 \mathrm{~g} / \mathrm{kg} \mathrm{CeO}_{2}$ exposure to soybean grown in soil induced the accumulations of $\mathrm{Cu}$ and $\mathrm{P}$, while it reduced the content of $\mathrm{Ca}$ in pods [183]. Nanocalcite $\left(40 \% \mathrm{CaCO}_{3}\right.$ ) with nano $\mathrm{Fe}_{2} \mathrm{O}_{3}(1 \%), \mathrm{MgO}(1 \%)$, and $\mathrm{SiO}_{2}$ (4\%) remarkably increased the intake of $\mathrm{P}$ with micronutrients $\mathrm{Mn}$ and $\mathrm{Zn}$, and enhanced the $\mathrm{Fe}, \mathrm{Ca}$, and $\mathrm{Mg}$ uptake [184]. The $\mathrm{Zn}, \mathrm{Fe}, \mathrm{Ca}$, and $\mathrm{K}$ contents increased after the seedlings were treated with Au NPs in wheat [185]. The supplementation of $\mathrm{ZnO}$ NPs with other fertilizers in the $\mathrm{Zn}$ deficient soil enhanced the productivity of barley by $91 \%$ compared to the control and increased nutrient use efficiency, while the conventional bulk $\mathrm{ZnSO}_{4}$ enhanced productivity by only $31 \%$ compared to the control [186]. Moreover, NPs with different hydrophobic properties have different changes in the content of elements in crops. Three different types (hydrophobic, hydrophilic, and unmodified) of $\mathrm{TiO}_{2} \mathrm{NPs}$ exposure to the seedlings have been reported to influence the mineral uptake in basil (Ocimum basilicum L.). At the concentration of $0.5 \mathrm{~g} / \mathrm{kg}$ treatment, the hydrophobic NPs induced Mn content by $339 \%$, the hydrophilic NPs induced the increase of Fe content by $90 \%$, and the unmodified ones increased the $\mathrm{Cu}$ by $104 \%$ ) and Fe by $90 \%$ [83]. Furthermore, nano-composite fertilizers showed helpful influences on rhizosphere microorganisms by inducing the secondary metabolite production [187, 188], improving the plant growth [189], and assisting the colonization on the root surface.

The application of controlled-release fertilizers, e.g., porous NMs, greatly improves the uptake process in crops by adjusting the demanded release [190]. A carbonbased NM, graphene oxide film, can extend the release of $\mathrm{KNO}_{3}$, which minimizes loss by runoff and leaching, and prolongs the time of effect [191]. Numerous studies have revealed that the decreasing size of NMs is beneficial to the increase of the surface mass ratio of particles. Various nutrient ions can be desorbed and adsorbed steadily and slowly for an extended period of time [192]. For example, the use of 'controlled release fertilizer' not only increased the wheat production and soil residual mineral nitrogen by $6 \%$ and $10 \%$, but also reduced nitrogen leaching and runoff loss by $25 \%$ and $22 \%$, respectively as compared to conventional fertilizers [193, 194]. Nano-fertilizers balance the nutrition during the life cycle and ultimately increase the production of crops.
Numerous studies were conducted on this topic, but the research and information on wider capacity are still inadequate. The study of the toxicity of NPs utilized for nano-composite fertilizer production and the safety of different nano-fertilizers applications should be the priority for research. Moreover, a further evaluation of the different effects of nano-fertilizers in soils with diverse physiochemical features is essential to endorse a specific nanofertilizer for a particular soil type or crop.

\section{Nanotechnology in pesticides}

The application of nanotechnology over conventional crop protection, e.g., over-dose and large-scale pesticide use, has rapidly increased to reach higher and better crop production.

\section{Insecticides}

At least $90 \%$ of the applied pesticides are either incapable to achieve the goals for effective control of insects or scattered in the environmental systems [195]. This situation not only leads to the deterioration of the environment but also increases the costs of crop production. It is important to note that the occurrence of active ingredients in the formulation at the lowest effective concentration at the target site is necessary to ensure improved protection of crops from an invasion of insects and subsequent loss of crops. Nano-encapsulation and nanoformulation of insecticides have completely changed crop protection. Nano-encapsulation of pesticides is a technology in which the active ingredients of insecticides are coated with various sizes of NMs [195]. Nano-formulation of insecticides includes a few particles, which can be used as insecticide active ingredients, and other engineered nano-structures have beneficial insecticidal features [196]. Nano-encapsulation and nano-formulation of insecticides assist the controlled release and persistence of active ingredients inside crops or in root zones without influencing the efficiency. Conventional formulations of insecticides not only harm non-target organisms, but also limit the water solubility of insecticides, causing increased resistance to target organisms. Nano-encapsulation and nano-formulation help to overcome the above limits [196]. Nano-encapsulation and nano-formulation of insecticides display many valuable features, such as increased thermal stability, crystallinity, solubility, permeability, stiffness, and also biodegradability essential for sustainable agricultural systems [197]. For instance, nanofibers formulation of pheromone in oriental fruit moth (Grapholita molesta L.) has no influences on mortality over time, signifying long-time attract-and-kill influence of insecticide and pheromone and a controlled release of active ingredients [198]. Moreover, some 
studies have delivered suggestions that the nanoformulations of insecticides help the broadening of plant-mediated universal resistance against insects. For instance, the formulations of $\mathrm{SiO}_{2}$ nanosphere can enhance the capability of insecticides to attain the cell sap and infiltrate through crops, thus applying the full function to regulate sucking or chewing type insects [199]. Hence, the NMs in insecticides have a marvelous possibility in pest management.

\section{Herbicides}

Weeds are invasive plants that reproduce or grow aggressively outside their original habitat [200]. The chemical ingredients of synthetic and biological sources, which restrain the growth of plants or kill them, are called herbicides [201]. Modern herbicides are frequently synthetic substances of endogenous hormones in varied plants, which can inhibit the development of objective crops. Although weeds are killed by the use of herbicides, occasionally overused herbicide applications largely influence plant growth, which also delivers harmfulness to human beings [202]. Nanotechnology has the ability for the effective transport of biological or synthetic herbicides by using NMs-based agrochemical formulations or nano-sized preparations [202]. The herbicides are loaded on different types of NPs to improve better removal of weeds and enable higher bioavailability. We can utilize the special characteristics (biodegradability, crystallinity, permeability, solubility, stiffness, and thermal stability) of NMs to develop different kinds of nanoherbicides. Nanoherbicides increase the affinity for the target by providing a larger specific surface area. Herbicides encapsulated in nanoscale help to efficient spraying by reducing the splash losses and spray drift. Nanoherbicides are mixed with the particles of soil and can damage weeds or weed seeds. Herbicides, such as triazine and atrazine could be encapsulated to develop effective release to crops [203]. The majority of accessible herbicides just kill aboveground sections of weeds, but do not prevent the growth of the underground viable sections like tubers or rhizomes that function as an origin for the next generation of weeds [204]. The development of particular molecules of the herbicides encapsulated with NPs aims to target receptors in the weed roots, which penetrates the weed roots and achieves sections that prevent the glycolysis process in roots, hence causing the death of specific weeds [205]. Long-term overuse of herbicides can leave their remains in soils and inhibit the growth of subsequent crops, so detoxification of herbicide remains is essential for sustainable development [206]. The detoxification rate of carboxymethyl cellulose NPs to atrazine herbicides is as high as $88 \%$ [207]. Thus, nanotechnology has the potential to improve the application range of herbicides and increase the duration of their effect.

\section{Bactericides}

Bactericides are any chemical substance of a synthetic or biological origin, which can inhibit bacterial growth or kill them [208]. The misuse of bactericide has led to the development of multi-drug-resistant bacteria, which is a significant global threat and is one of the biggest challenges for agricultural activities. Nanotechnologydriven innovations provide hope for overcoming this problem [209]. The effectiveness of NPs depends on their interaction with microorganisms. The development of effective NMs requires in-depth knowledge of the biological aspects of microorganisms and the physicochemical properties of NPs. Metallic oxide NPs, such as MgO [210], $\mathrm{Al}_{2} \mathrm{O}_{3}$ [211], $\mathrm{MnO}, \mathrm{SiO}$, and $\mathrm{TiO}$ [212], $\mathrm{ZnO}$ and $\mathrm{CuO}$ [213], have been shown to successfully regulate various crops and soil-borne diseases produced by Ralstonia solanacearum [210], Fusarium oxysporum [211, 212], Verticillium Dahliae, Fusarium solani, Monilinia fructicola, Colletotrichum gloeosporioides, Botrytis cinerea, and Alternaria alternate [213] in various crops. Furthermore, communities of the microorganism of soil have a direct influence on the quality of soil by various processes, such as symbiotic relationships with the decomposition of organic matter, terrestrial crops, and nutrient cycling [214]. Thus, the protection of soil microbial diversity and biomass is the main task for agricultural systems. The metallic oxide NPs, such as $\mathrm{CuO}$ and $\mathrm{Fe}_{3} \mathrm{O}_{4}$ NPs, have a big influence on the size and composition of the microbial communities in the soils [215]. Due to the physicochemical properties of NPs, they provide hope for the development of effective antimicrobial agents for the future.

\section{Conclusions}

In the last decade, nanotechnology obtain enormous achievements in the design and synthesis of NMs and their use in therapy, diagnosis, or other medical purposes. Due to high cost or other factors, applications of nanotechnology in crops cannot be widely utilized in agricultural activities or practices. (i) Despite the great improvement of nanotechnology in plant genetics and crop breeding, the delivery of exogenous enzymes or DNA for genome editing is still a tough task. Based on evidence found in plant cells, soft materials, like polymeric nanostructures, and nanogels can be utilized as promising substances to advance novel approaches for genome editing and controlled release of biomolecules in crops. (ii) The troubles of phytonanotechnology can be conquered by encouraging multidisciplinary manners for the synthesis or design of intelligent NMs. To 
this end, a joint collaborative initiative that merges the complementary professional capabilities of chemists, biochemists, engineers, geneticists, and botanists may reveal a new horizon in phytonanotechnology. (iii) Regarding crop growth and development, current applications propose that more studies are needed for this direction to ameliorate the sustainability of agricultural systems. Future studies involving open-field trials may further benefit to recognizing the mechanism of NPs action on crops.

When used in the agricultural system, these NPs need to be carefully designed, considering their treatment methods (soil or foliar), so that they can have a high impact and ensure a better quality of crops. Meanwhile, excessive use of these NMs may pollute the environment, thus special care must be adopted while working with NMs in plant systems. However, it is an undeniable fact that the positive functions of NPs have shown great efforts to numerous aspects in agricultural systems starting from germination to postharvest.

\begin{abstract}
Abbreviations
NMs: Nanomaterials; NPs: Nanoparticles; MSNs: Mesoporous silica NPs; CNTs: Carbon nanotubes; QDs: Quantum dots; MNPs: Magnetic NPs; GFP: Green fluorescent protein; MWNTs: Multi-walled nanotubes; SWNTs: Single-walled nanotubes; VNPs: Virus-like NPs; CRISPR: Clustered regularly interspaced short palindromic repeats; Cas: CRISPR-associated proteins; sgRNA: Single guide RNA; RNP: Ribonucleoproteins; ROS: Reactive oxygen species; PS II: Photosystem II; LHCII: Light-harvesting complex II; UV: Ultraviolet; SN: Sodium nitroprusside.
\end{abstract}

\section{Acknowledgements}

Not applicable.

\section{Authors' contributions}

$\mathrm{JZ}$ and $\mathrm{MJ}$ proposed the project; all the authors carried out reference searching and data analysis; MJ and YS wrote the manuscript; MKK, GJA, SS, and $J Z$ made review and final editing. All authors read and approved the final manuscript.

\section{Funding}

This work was supported by the National Key Research and Development Program of China (2019YFD1000300), the National Natural Science Foundation of China (31922078 and 31872089), the Starry Night Science Fund of Zhejiang University Shanghai Institute for Advanced Study (SN-ZJU-SIAS-0011), the Postdoctoral Science Foundation of China (2020M680078), and the Postdoctoral Science Foundation of Zhejiang Province (ZJ2020157).

\section{Declarations}

Ethics approval and consent to participate Not applicable.

\section{Consent for publication}

Not applicable.

\section{Competing interests}

The authors declare that they have no competing interests.

\section{Author details}

${ }^{1}$ College of Agriculture and Biotechnology, Zhejiang University, Yuhangtang Road 866, Hangzhou 310058, People's Republic of China. ${ }^{2}$ Institute of Crop
Sciences, National Key Laboratory of Rice Biology, Zhejiang University, Yuhangtang Road 866, Hangzhou 310058, People's Republic of China. ${ }^{3}$ Department of Horticulture, Zhejiang Provincial Key Laboratory of Horticultural Plant Integrative Biology, Zhejiang University, Yuhangtang Road 866, Hangzhou 310058, People's Republic of China. ${ }^{4}$ Key Laboratory of Horticultural Plants Growth, Development and Quality Improvement, Agricultural Ministry of China, Yuhangtang Road 866, Hangzhou 310058, People's Republic of China. ${ }^{5}$ College of Horticulture and Plant Protection, Henan University of Science and Technology, Luoyang 471023, People's Republic of China.

Received: 26 August 2021 Accepted: 2 December 2021

Published online: 20 December 2021

\section{References}

1. Wang P, Lombi E, Zhao F, Kopittke PM. Nanotechnology: a new opportunity in plant sciences. Trends Plant Sci. 2016;21 (8):699-712.

2. Pandey G. Challenges and future prospects of agrinanotechnology for sustainable agriculture in India. Environ Technol Innov. 2018;11:299-307.

3. Acharya A, Pal PK. Agriculture nanotechnology: translating research outcome to field applications by influencing environmental sustainability. Nanolmpact. 2020;19:100232.

4. Salama DM, Abd El-Aziz ME, Rizk FA, Abd Elwahed MSA. Applications of nanotechnology on vegetable crops. Chemosphere. 2021;266:129026

5. Fincheira P, Tortella G, Seabra AB, Quiroz A, Diez MC, Rubilar O. Nanotechnology advances for sustainable agriculture: current knowledge and prospects in plant growth modulation and nutrition. Planta. 2021;254(4):66.

6. Rodriques SM, Demokritou P, Dokoozlian N, Hendren CO, Karn B, Mauter MS, Sadik OA, Safarpour M, Unrine JM, Viers J, Welle P, White JC, Wiesner MR, Lowry G. Nanotechnology for sustainable food production: promising opportunities and scientific challenges. Environ Sci Nano. 2017:4(4):767-81.

7. Nair R, Varghese SH, Nair BG, Maekawa T, Yoshida Y, Kumar DS. Nanoparticulate material delivery to plants. Plant Sci. 2010;179:154-63.

8. Nel A, Xia T, Madler L, Li N. Toxic potential of materials at the nanolevel. Science. 2006;311:622-7.

9. Shang Y, Hasan MK, Ahammed GJ, Li M, Yin H, Zhou J. Applications of nanotechnology in plant growth and crop protection: a review. Molecules. 2019;24:2558.

10. Torney F, Trewyn BG, Lin VS, Wang K. Mesoporous silica nanoparticles deliver DNA and chemicals into plants. Nat Nanotechnol. 2007;2(5):295-300.

11. Martin-Ortigosa S, Peterson DJ, Valenstein JS, Lin VS, Trewyn BG, Lyznik LA, Wang K. Mesoporous silica nanoparticle-mediated intracellular Cre protein delivery for maize genome editing via loxP site excision. Plant Physiol. 2014;164:537-47.

12. Chang $X$, Song $Z, X u Y$, , Gao M. Effects of carbon nanotubes on growth of wheat seedlings and Cd uptake. Chemosphere. 2020;240:124931.

13. Kargozar S, Hoseini SJ, Milan PB, Hooshmand S, Kim HW, Mozafari M. Quantum dots: a review from concept to clinic. Biotechnol J. 2020;15(12):e2000117.

14. Huang X, Barry BD, Cheng H, Malyutin A, Tsvetkova IB, Baxter DV, Remmes NB, Verchot J, Kao C, Bronstein LM, Dragnea B. Magnetic virus-like nanoparticles in $N$. benthamiana plants: a new paradigm for environmental and agro-nomic biotechnological research. ACS Nano. 2011:5:4037-45

15. Corredor E, Testillano PS, Coronado M, González-Melendi P, FernándezPacheco R, Marquina C, Ibarra MR, de la Fuente JM, Rubiales D, Pérezde-Luque A, Risueño M. Nanoparticle penetration and transport in living pumpkin plants: in situ subcellular identification. BMC Plant Biol. 2009:9:45.

16. Jahan S, Alias YB, Bakar AFBA, Yusoff IB. Toxicity evaluation of ZnO and $\mathrm{TiO}_{2}$ nanomaterials in hydroponic red bean (Vigna angularis) plant: physiology, biochemistry and kinetic transport. J Environ Sci. 2018;72:140-52.

17. Gogos A, Knauer K, Bucheli TD. Nanomaterials in plant protection and fertilization: current state, foreseen applications, and research priorities. J Agric Food Chem. 2012;60:9781-92. 
18. Scheringer M. Nanoecotoxicology: environmental risks of nanomaterials. Nat Nanotechnol. 2008;3:322-3.

19. Wang W, Yuan J, Jiang C. Applications of nanobodies in plant science and biotechnology. Plant Mol Biol. 2021;105:43-53.

20. Wang Y, Deng C, Cota-Ruiz K, Peralta-Videa JR, Sun Y, Rawat S, Tan W, Reyes A, Hernandez-Viezcas JA, Niu G, Li C, Gardea-Torresdey JL. Improvement of nutrient elements and allicin content in green onion (allium fistulosum) plants exposed to cuo nanoparticles. Sci Total Environ. 2020:725:138387

21. da Cruz TNM, Savassa SM, Montanha GS, Ishida JK, de Almeida E, Tsai SM, Junior JL, de Carvalho HWP. A new glance on root-to-shoot in vivo zinc transport and time-dependent physiological effects of $\mathrm{ZnSO}_{4}$ and ZnO nanoparticles on plants. Sci Rep. 2020;9:10416.

22. Salehi H, Diego ND, Rad AC, Benjamin JJ, Lucini L. Exogenous application of $\mathrm{ZnO}$ nanoparticles and $\mathrm{ZnSO}_{4}$ distinctly influence the metabolic response in Phaseolus vulgaris L. Sci Total Environ. 2021;778:146331.

23. Bandyopadhyay S, Plascencia-Villa G, Mukherjee A, Rico CM, JoséYacamán M, Peralta-Videa JR, Gardea-Torresdey JL. Comparative phytotoxicity of $\mathrm{ZnO}$ NPs, bulk $\mathrm{ZnO}$, and ionic zinc onto the alfalfa plants symbiotically associated with Sinorhizobium melilotiin soil. Sci Total Environ. 2015;15(515-516):60-9.

24. García-Gómez C, Obrador A, González D, Babín M, Fernández MD. Compara-tive study of the phytotoxicity of $\mathrm{ZnO}$ nanoparticles and $\mathrm{Zn}$ accumulation in nine crops grown in a calcareous soil and an acidic soil. Sci Total Environ. 2018;644:770-80.

25. Yang Q, Xu W, Liu G, Song M, Tan Z, Mao Y, Yin Y, Cai Y, Liu J, Jiang G. Transformation and uptake of silver nanoparticles and silver ions in rice plant (Oryza sativa L.): the effect of iron plaque and dissolved iron. Environ Sci Nano. 2020;7:599-609.

26. Deshpande P, Dapkekar A, Oak MD, Paknikar KM, Rajwade JM. Zinc complexed chitosan/TPP nanoparticles: a promising micronutrient nanocarrier suited for foliar application. Carbohyd Polym. 2017;165:394-401.

27. Jalali M, Ghanati F, Modarres-Sanavi AM, Khoshgoftarmanesh AH. Physiological effects of repeated foliar application of magnetite nanoparticles on maize plants. J Agron Crop Sci. 2017;203(6):593-602.

28. Achari GA, Kowshik M. Recent developments on nanotechnology in agriculture: plant mineral nutrition, health, and interactions with soil microflora. J Agron Crop Sci. 2018:66(33):8647-61.

29. Su Y, Ashworth V, Kim C, Adeleye AS, Rolshausen P, Roper C, White J, Jassby D. Delivery, uptake, fate, and transport of engineered nanoparticles in plants: a critical review and data analysis. Environ Sci Nano. 2019;6(8):2311-31.

30. Sturikova H, Krystofova O, Huska D, Adam V. Zinc, zinc nanoparticles and plants. J Hazard Mater. 2018;349:101-10.

31. Ma C, White JC, Zhao J, Zhao Q, Xing B. Uptake of engineered nanoparticles by food crops: characterization, mechanisms, and implications. Annu Rev Food Sci Technol. 2018;9:129-53.

32. Duhan JS, Kumar R, Kumar N, Kaur P, Nehra K, Duhan S. Nanotechnology: the new perspective in precision agriculture. Biotechnol Rep. 2017;15:11-23.

33. Shahrekizad M, Ahangar AG, Mir N. EDTA-Coated $\mathrm{Fe}_{3} \mathrm{O}_{4}$ nanoparticles: a novel biocompatible fertilizer for improving agronomic traits of sunflower (Helianthus Annuus). J Nanostruct. 2015:5:117-27.

34. Rathore I, Tarafdar JC. Perspectives of biosynthesized magnesium nanoparticles in foliar application of wheat plant. J Bionanosci. 2015;9(3):209-14.

35. Karny A, Zinger A, Kajal A, Shainsky-Roitman J, Schroeder A. Therapeutic nanoparticles penetrate leaves and deliver nutrients to agricultural crops. Sci Rep. 2018;8(1):7589.

36. Nadendla SR, Rani TS, Vaikuntapu PR, Maddu RR, Podile AR. HarpinPsS encapsulation in chitosan nanoparticles for improved bioavailability and disease resistance in tomato. Carbohyd Polym. 2018;199:11-9.

37. Hu P, An J, Faulkner MM, Wu H, Li Z, Tian X, Giraldo JP. Nanoparticle charge and size control foliar delivery efficiency to plant cells and organelles. ACS Nano. 2020;14(7):7970-86.

38. Su Y, Ashworth V, Geitner NK, Wiesner MR, Ginnan N, Rolshausen P, Roper C, Jassby D. Delivery, fate, and mobility of silver nanoparticles in citrus trees. ACS Nano. 2020;14(3):2966-81.

39. Elmer WH, White JC. The use of metallic oxide nanoparticles to enhance growth of tomatoes and eggplants in disease infested soil or soilless medium. Environ Sci Nano. 2016:3(5):1072-9.
40. Yu M, Yao J, Liang J, Zeng Z, Cui B, Zhao X, Sun C, Wang Y, Liu G, Cui H. Development of functionalized abamectin poly(lactic acid) nanoparticles with regulatable adhesion to enhance foliar retention. RSC Adv. 2017;7(19):11271-80.

41. Ahmar S, Gill RA, Jung KH, Faheem A, Qasim MU, Mubeen M, Zhou W. Conventional and molecular techniques from simple breeding to speed breeding in crop plants: recent advances and future outlook. Int J Mol Sci. 2020;21:2590.

42. Ahmar S, Mahmood T, Fiaz S, Mora-Poblete F, Shafique MS, Chattha MS, Jung KH. Advantage of nanotechnology-based genome editing system and its application in crop improvement. Front Plant Sci. 2021;12:663849.

43. Joga MR, Zotti MJ, Smagghe G, Christiaens O. RNAi efficiency, systemic properties, and novel delivery methods for pest insect control: what we know so far. Front Physiol. 2016;7:553.

44. Zhao L, Lu L, Wang A, Zhang H, Huang M, Wu H, Xing B, Wang Z, Ji R. Nano-biotechnology in agriculture: use of nanomaterials to promote plant growth and stress tolerance. J Agric Food Chem. 2020;68(7):1935-47

45. Yan Y, Zhu X, Yu Y, Li C, Zhang Z, Wang F. Nanotechnology strategies for plant genetic engineering. Adv Mater. 2021;26:e2106945.

46. Galbraith DW. Nanobiotechnology-Silica breaks through in plants. Nat Nanotechnol. 2007:2:272-3.

47. Ozyigit II, Kurtoglu KK. Particle bombardment technology and its applications in plants. Mol Biol Rep. 2020:47(12):9831-47.

48. Vijayakumar PS, Abhilash OU, Khan BM, Prasad BLV. Nanogold-loaded sharp-edged carbon bullets as plant-gene carriers. Adv Funct Mater. 2010;20:2416-23.

49. Lau HY, Wu H, Wee EJH, Trau M, Wang Y, Botella JR. Specific and sensitive isothermal electrochemical biosensor for plant pathogen DNA detection with colloidal gold nanoparticles as probes. Sci Rep. 2017:7:38896.

50. Zhao X, Meng Z, Wang Y, Chen W, Sun C, Cui B, Cui J, Yu M, Zeng Z, Guo S, Luo D, Cheng J, Zhang R, Cui H. Pollen magnetofection for genetic modification with magnetic nanoparticles as gene carriers. Nat Plants. 2017:3:956-64.

51. Demirer GS, Zhang H, Matos J, Goh N, Cunningham FJ, Sung Y, Chang R, Aditham AJ, Chio L, Cho M, Staskawicz B, Landry MP. High aspect ratio nanomaterials enable delivery of functional genetic material without DNA integration in mature plants. Nat Nanotechnol. 2019;14:456-64.

52. Demirer G, Zhang H, Goh N, Pinals R, Chang R, Landry M. Carbon nanocarriers deliver siRNA to intact plant cells for efficient gene knockdown. Sci Adv. 2020;6:eaaz0495.

53. Zhang X, Zhang J, Zhu Y. Chitosan/double-stranded RNA nanoparticlesmediated RNA interference to silence chitin synthase genes through larval feeding in the African malaria mosquito (Anopheles gambiae). Insect Mol Biol. 2010;19:683-93.

54. Mitter N, Worrall EA, Robinson KE, Li P, Jain RG, Taochy C, Fletcher SJ, Carroll BJ, Lu GQ, Xu ZP. Clay nanosheets for topical delivery of RNAi for sustained protection against plant viruses. Nat Plants. 2017:3:16207.

55. Tan YY, Du H, Wu X, Liu YH, Jiang M, Song SY, Wu L, Shu QY. Gene editing: a machinery to cash gene biology in plant breeding. J Zhejiang Univ-Sci B. 2020;21(6):460-73.

56. Miller JB, Zhang S, Kos $\mathrm{P}$, Xiong H, Zhou K, Perelman SS, Zhu H, Siegwart DJ. Non-viral CRISPR/Cas gene editing in vitro and in vivo enabled by synthetic nanoparticle co-delivery of Cas 9 mRNA and sgRNA. Angew Chem Int Ed. 2017:56:1059-63.

57. Demirer G, Silva T, Jackson C, Thomas J, Ehrhardt D, Rhee S, Mortimer J, Landry M. Nanotechnology to advance CRISPR-Cas genetic engineering of plants. Nat Nanotechnol. 2021;16:1-8.

58. Mout R, Ray M, Yesilbag Tonga G, Lee YW, Tay T, Sasaki K, Rotello VM. Direct cytosolic delivery of CRISPR/Cas9-ribonucleoprotein for efficient gene editing. ACS Nano. 2017;11:2452-8.

59. Dubey A, Mailapalli DR. Nanofertilisers, nanopesticides, nanosensors of pest and nanotoxicity in agriculture. Sustain Agric Rev. 2016;19:307-30.

60. Nair R. Effects of nanoparticles on plant growth and development. Plant Nanotechnol. 2016:5:95-118.

61. Siddiqi KS, Husen A. Plant response to engineered metal oxide nanoparticles. Nanoscale Res Lett. 2017;12(1):92.

62. Manjaiah KM, Mukhopadhyay R, Paul R, Datta SC, Kumararaja P, Sarkar B. Clay minerals and zeolites for environmentally sustainable agriculture. 
In: Modified clay and zeolite nanocomposite materials, vol. 13 2019:309-29.

63. Abou-Zeid HM, Ismail GSM, Abdel-Latif SA. Influence of seed priming with zno nanoparticles on the salt-induced damages in wheat (Triticum aestivum L.) plants. J Plant Nutr. 2020;44(1):1-15.

64. Banerjee J, Kole C. Plant nanotechnology: an overview on concepts, strategies, and tools. Plant Nanotechnol. 2016;1:1-14

65. Li Y, Liang L, Li W, Ashraf U, Ma L, Tang X, Pan S, Tian H, Mo Z. ZnO nanoparticle-based seed priming modulates early growth and enhances physio-biochemical and metabolic profiles of fragrant rice against cadmium toxicity. J Nanobiotechnol. 2021;19(1):75.

66. Raskar SV, Laware SL. Effect of zinc oxide nanoparticles on cytology and seed germination in onion. Int J Curr Microbiol Appl Sci. 2014;3:467-73.

67. Sedghi M, Hadi M, Toluie SG. Effect of nano zinc oxide on the germination of soybean seeds under drought stress. Ann West Univ Timisoara Ser Biol. 2013;16(2):73-8.

68. Joshi A, Kaur S, Dharamvir K, Nayyar H, Verma G. Multi-walled carbon nanotubes applied through seed-priming influence early germination, root hair, growth and yield of bread wheat (Triticum aestivum L.). J Sci Food Agric. 2018;98:3148-60.

69. Lahiani MH, Dervishi E, Chen JH, Nima Z, Gaume A, Biris AS, Khodakovskaya MV. Impact of carbon nanotube exposure to seeds of valuable crops. ACS Appl Mater Interfaces. 2013;5:7965-73.

70. Srivastava A, Rao D. Enhancement of seed germination and plant growth of wheat, maize, peanut and garlic using multiwalled carbon nanotubes. Eur Chem Bull. 2014;3:502-4.

71. Yan S, Zhao L, Li H, Zhang Q, Tan J, Huang M, He H, Li L. Singlewalled carbon nanotubes selectively influence maize root tissue development accompanied by the change in the related gene expression. J Hazard Mater. 2013;246-247:110-8.

72. Wang $Q$, Yang S, Wan S, Li X. The significance of calcium in photosynthesis. Int J Mol Sci. 2019;20(6):1353.

73. Newkirk GM, de Allende P, Jinkerson RE, Giraldo JP. Nanotechnology approaches for chloroplast biotechnology advancements. Front Plant Sci. 2021;12:691295.

74. Rossi L, Fedenia LN, Sharifan H, Ma X, Lombardini L. Effects of foliar application of zinc sulfate and zinc nanoparticles in coffee (Coffea arabica L.) plants. Plant Physiol Biochem. 2019;135:160-6.

75. Chand N, Siddiqui N. Improvement in thermo mechanical and optical properties of in situ synthesized PMMA/TiO2 nanocomposite. Compos Interfaces. 2012;19:51-8.

76. Siddiqui $\mathrm{MH}, \mathrm{Al}-$ Whaibi $\mathrm{MH}$, Faisal M, Al Sahli AA. Nano-silicon dioxide mitigates the adverse effects of salt stress on Cucurbita pepo L. Environ Toxicol Chem. 2014;33:2429-37.

77. Sun D, Hussain HI, Yi Z, Rookes JE, Kong L, Cahill DM. Mesoporous silica nanoparticles enhance seedling growth and photosynthesis in wheat and lupin. Chemosphere. 2016;152:81-91.

78. Rafique R, Zahra Z, Virk N, Shahid M, Pinelli E, Park TJ, Kallerhoff J, Arshad M. Dose-dependent physiological responses of Triticum aestivum L. to soil applied $\mathrm{TiO}_{2}$ nanoparticles: alterations in chlorophyll content, $\mathrm{H}_{2} \mathrm{O}_{2}$ production, and genotoxicity. Agr Ecosyst Environ. 2018;255:95-101.

79. Lee CW, Mahendra S, Zodrow K, Li D, Tsai T, Braam J, Alvarez PJJ. Developmental phytotoxicity of metal oxide nanoparticles to Arabidopsis thaliana. Environ Toxicol Chem. 2010;29(3):669-75.

80. Li P, Song A, Li ZJ, Fan F, Liang Y. Silicon ameliorates manganese toxicity by regulating both physiological processes and expression of genes associated with photosynthesis in rice (Oryza sativa L.). Plant Soil. 2015:397:289-301.

81. Song A, Li P, Fan FL, Li Z, Liang Y. The effect of silicon on photosynthesis and expression of its relevant genes in rice (Oryza sativa L.) under high zinc stress. PLoS ONE. 2014;9:e113782.

82. Jalali M, Ghanati $\mathrm{F}$, Modarres-Sanavi AM. Effect of $\mathrm{Fe}_{3} \mathrm{O}_{4}$ nanoparticles and iron chelate on the antioxidant capacity and nutritional value of soil-cultivated maize (Zea mays) plants. Crop Pasture Sci. 2016;67:621-8.

83. Tan W, Du W, Barrios AC, Armendariz R, Zuverza-Mena N, Ji Z, Chang $\mathrm{CH}$, Zink JI, Hernandez-Viezcas JA, Peralta-Videa JR, Gardea-Torresdey $J$. Surface coating changes the physiological and biochemical impacts of nano- $\mathrm{TiO}_{2}$ in basil (Ocimum basilicum) plants. Environ Pollut. 2017;222:64-72

84. López-Vargas ER, Ortega-Ortíz H, Cadenas-Pliego G, de Alba Romenus K, Cabrera de la Fuente M, Benavides-Mendoza A, Juárez-Maldonado
A. Foliar application of copper nanoparticles increases the fruit quality and the content of bioactive compounds in tomatoes. Appl Sci. 2018:8(7):1-15

85. Ke M, Li Y, Qu Q, Ye Y, Peijnenburg W, Zhang Z, Xu N, Lu T, Sun L, Qian H. Offspring toxicity of silver nanoparticles to Arabidopsis thaliana flowering and floral development. J Hazard Mater. 2020;386:121975.

86. He X, Deng H, Hwang HM. The current application of nanotechnology in food and agriculture. J Food Drug Anal. 2019;27(1):1-21.

87. Dekkers S, Krystek P, Peters RJ, Lankveld DX, Bokkers BG, van HoevenArentzen PH, Bouwmeester H, Oomen AG. Presence and risks of nanosilica in food products. Nanotoxicology. 2011;5:393-405.

88. Nakagawa K. Nano- and micro-encapsulation of flavor in food systems. In: Nano- and microencapsulation for foods, vol. 10. 2014: 249-72.

89. Yang R, Zhou Z, Sun G, Gao Y, Xu J, Strappe P, Blanchard C, Cheng Y, Ding $X$. Synthesis of homogeneous protein-stabilized rutin nanodispersions by reversible assembly of soybean (Glycine max) seed ferritin. RSC Adv. 2015;5:31533-40.

90. Zielińska A, Carreiró F, Oliveira AM, Neves A, Pires B, Venkatesh DN, Durazzo A, Lucarini M, Eder P, Silva AM, Santini A, Souto EB. Polymeric nanoparticles: production, characterization, toxicology and ecotoxicology. Molecules. 2020;25(16):3731.

91. Sahani S, Sharma YC. Advancements in applications of nanotechnology in global food industry. Food Chem. 2021;342:128318.

92. Shaheen A, Abed Y. Knowledge, attitude, and practice among farmworkers applying pesticides in cultivated area of the Jericho district: a cross-sectional study. Lancet. 2018;391:S3.

93. Bajželj B, Richards KS, Allwood JM, Smith P, Dennis JS, Curmi E, Gilligan A. Importance of food-demand management for climate mitigation. Nat Clim Chang. 2014;4:924-9.

94. Torres-Giner S, Prieto C, Lagaron JM. Nanomaterials to enhance food quality, safety, and health impact. Nanomaterials. 2020;10:941.

95. Couch LM, Wien M, Brown JL, Davidson P. Food nanotechnology: proposed uses, safety concerns and regulations. Agro Food Ind Hi-tech. 2016;27:36-9.

96. Mihindukulasuriya SDF, Lim LT. Nanotechnology development in food packaging: a review. Trends Food Sci Technol. 2014;40:149-67.

97. Bhuyan D, George WG, Ratul KD. Prospects and application of nanobiotechnology in food preservation: molecular perspectives. Crit Rev Biotechnol. 2019;39(6):759-78.

98. Zou L, Peng S, Liu W, Chen X, Liu C. A novel delivery system dextran sulfate coated amphiphilic chitosan derivatives-based nanoliposome: capacity to improve in vitro digestion stability of (_)-epigallocatechin gallate. Food Res Int. 2015;69:114-20.

99. Taherkhani S, Mohammadi M, Daoud J, Martel S, Tabrizian M. Covalent binding of nanoliposomes to the surface of magnetotactic bacteria for the synthesis of self-propelled therapeutic agents. ACS Nano. 2014;8:5049-60.

100. Ma Y, Wang Z, Zhao W, Lu T, Wang R, Mei Q, Chen T. Enhanced bactericidal potency of nanoliposomes by modification of the fusion activity between liposomes and bacterium. Int J Nanomed. 2013;8:2351.

101. Gupta A, Eral HB, Hatton TA, Doyle PS. Nanoemulsions: formation, properties and applications. Soft Matter. 2016;12:2826-41.

102. Salvia-Trujillo L, Rojas-Grau MA, Soliva-Fortuny R, Martín-Belloso O. Impact of microfluidization or ultrasound processing on the antimicrobial activity against Escherichia coli of lemongrass oil-loaded nanoemulsions. Food Control. 2014;37:292-7.

103. Han JH. Edible films and coatings: a review. In: Innovations in food packaging, vol. 9. 2014:213-55.

104. Adiletta G, Di Matteo M, Petriccione M. Multifunctional role of chitosan edible coatings on antioxidant systems in fruit crops: a review. Int J Mol Sci. 2021;22(5):2633

105. Otoni CG, Avena-Bustillos RJ, Azeredo HMC, Lorevice MV, Moura MR, Mattoso LHC, Mchugh TH. Recent advances on edible films based on fruits and vegetables-a review. Compr Rev Food Sci Food Saf. 2017; 16:1151-69.

106. Becaro AA, Puti FC, Correa DS, Paris EC, Marconcini JM, Ferreira MD. Polyethylene films containing silver nanoparticles for applications in food packaging: characterization of physicochemical and anti-microbial properties. J Nanosci Nanotechnol. 2015;15:2148-56. 
107. Metak MM. Effects of nanocomposite based nano-silver and nanotitanium dioxide on food packaging materials. Int J Appl Sci Technol. 2015;5:26-40.

108. Murphy M, Ting K, Zhang X, Soo C, Zheng Z. Current development of silver nanoparticle preparation, investigation, and application in the field of medicine. J Nanomater. 2015;8433:1-12.

109. Yemmireddy VK, Hung YC. Effect of binder on the physical stability and bactericidal property of titanium dioxide $\left(\mathrm{TiO}_{2}\right)$ nanocoatings on food contact surfaces. Food Control. 2015:57:82-8.

110. Weir A, Westerhoff P, Fabricius L, Hristovski K, Goetz NV. Titanium dioxide nanoparticles in food and personal care products. Environ Sci Technol. 2012:46:2242-50.

111. Pathakoti K, Morrow S, Han C, Pelaez M, He X, Dionysiou DD, Hwang HM. Photoinactivation of Escherichia coli by sulfur-doped and nitrogen-fluorine-codoped $\mathrm{TiO}_{2}$ nanoparticles under solar simulated light and visible light irradiation. Environ Sci Technol. 2013;47:9988-96.

112. Andy P. Plant abiotic stress challenges from the changing environment. Front Plant Sci. 2016;7:1123.

113. Husen A, Iqbal M, Aref IM. IAA-induced alteration in growth and photosynthesis of pea (Pisum sativum L.) plants grown under salt stress. J Environ Biol. 2016;37:421-9.

114. Rajput VD, Minkina T, Kumari A, Harish, Keswani C. Coping with the challenges of abiotic stress in plants: new dimensions in the field application of nanoparticles. Plants. 2021;10(6):1221.

115. Wu HH, Li ZH. Recent advances in nano-enable agriculture for improving plant performance. Crop J. 2021. https://doi.org/10.1016/j. cj.2021.06.002.

116. Myint KZ, Yu Q, Xia Y, Qing J, Zhu S, Fang Y, Shen J. Bioavailability and antioxidant activity of nanotechnology-based botanic antioxidants. J Food Sci. 2021;86(2):284-92.

117. Khodakovskaya MV, de Silva K, Nedosekin DA, Dervishi E, Biris AS, Shashkov EV, Ekaterina IG, Zharov VP. Complex genetic, photo thermal, and photo acoustic analysis of nanoparticle-plant interactions. Proc Natl Acad Sci USA. 2011;108:1028-33.

118. Zhao L, Peng B, Hernandez-Viezcas JA, Rico C, Sun Y, Peralta-Videa JR, Tang X, Niu G, Jin L, Ramirez AV, Zhang JY, Gardea-Torresdey JL. Stress response and tolerance of Zea mays to $\mathrm{CeO}_{2}$ nanoparticles: cross talk among $\mathrm{H}_{2} \mathrm{O}_{2}$, heat shock protein and lipid peroxidation. ACS Nano. 2012;6:9615-22.

119. Qi M, Liu Y, LiT. Nano-TiO improve the photosynthesis of tomato leaves under mild heat stress. Biol Trace Elem Res. 2013;156:323-8.

120. labal M, Raja NI, Mashwani ZR, Hussain M, Ejaz M, Yasmeen F. Effect of silver nanoparticles on growth of wheat under heat stress. Iran J Sci Technol Trans Sci. 2017;43:387-95.

121. Abou-Zeid HM, Ismail GSM. The role of priming with biosynthesized silver nanoparticles in the response of Triticum aestivum L. to salt stress. Egypt J Bot. 2018;58:73-85.

122. Djanaguiraman M, Belliraj N, Bossmann SH, Prasad PVV. High-temperature stress alleviation by selenium nanoparticle treatment in grain sorghum. ACS Omega. 2018;3:2479-91.

123. Azimi R, Borzelabad MJ, Feizi H, Azimi A. Interaction of $\mathrm{SiO} 2$ nanoparticles with seed prechilling on germination and early seedling growth of tall wheatgrass (Agropyron elongatum L.). Pol J Chem Technol. 2014;16:25-9.

124. Haghighi M, Abolghasemi R, Teixeira da Silva JA. Low and high temperature stress affect the growth characteristics of tomato in hydroponic culture with Se and nano-Se amendment. Sci Hortic. 2014;178:231-40.

125. Hasanpour $\mathrm{H}$, Maali-Amiri R, Zeinali $\mathrm{H}$. Effect of $\mathrm{TiO}_{2}$ nanoparticles on metabolic limitations to photosynthesis under cold in chickpea. Russ $\mathrm{J}$ Plant Physiol. 2015;62:779-87.

126. Song $Y$, Jiang $M$, Zhang $H L$, Li RQ. Zinc oxide nanoparticles alleviate chilling stress in rice (Oryza sativa L.) by regulating antioxidative system and chilling response transcription factors. Molecules. 2021;26(8):2196.

127. Haghighi M, Pourkhaloee A. Nanoparticles in agricultural soils: their risks and benefits for seed germination. Miner Biotecnol. 2013;25:123-32.

128. Almutairi ZM. Effect of nano-silicon application on the expression of salt tolerance genes in germinating tomato (Solanum lycopersicum L.) seedlings under salt stress. Plant Omics J. 2016;9:106-14.

129. Bruna HCO, Gomes CR, Milena T, Pelegrino A, Seabra B. Nitric oxidereleasing chitosan nanoparticles alleviate the effects of salt stress in maize plants. Nitric Oxide. 2016;61:10-9.
130. Martinez-Ballesta MC, Zapata L, Chalbi N, Carvajal M. Multiwalled carbon nanotubes enter broccoli cells enhancing growth and water uptake of plants exposed to salinity. J Nanobiotechnol. 2016;14:42.

131. Torabian S, Zahedi M, Khoshgoftar AH. Effects of foliar spray of two kinds of zinc oxide on the growth and ion concentration of sunflower cultivars under salt stress. J Plant Nutr. 2016;39:172-80.

132. Askary M, Talebi SM, Amini F, Bangan ADB. Effects of iron nanoparticles on Mentha piperita under salinity stress. Biologija. 2017;63:65-75.

133. Fathi A, Zahedi M, Torabian S, Khoshgoftar A. Response of wheat genotypes to foliar spray of $\mathrm{ZnO}$ and $\mathrm{Fe}_{2} \mathrm{O}_{3}$ nanoparticles under salt stress. J Plant Nutr. 2017:40:1376-85.

134. Alsaeedi A, El-Ramady A, Alshaal T, El-Garawani M, Elhawat N, Al-Otaibi A. Exogenous nanosilica improves germination and growth of cucumber by maintaining $\mathrm{K}+/ \mathrm{Na}+$ ratio under elevated $\mathrm{Na}+$ stress. Plant Physiol Biochem. 2018;125:164-71.

135. Farhangi-Abriz S, Torabian S. Nano-silicon alters antioxidant activities of soybean seedlings under salt toxicity. Protoplasma. 2018;255:953-62.

136. Hernandez-Hernandez H, Gonzalez-Morales S, Benavides-Mendoza A, Ortega-Ortiz H, Cadenas-Pliego G, Juarez-Maldonado A. Effects of chitosan-PVA and Cu nanoparticles on the growth and antioxidant capacity of tomato under saline stress. Molecules. 2018;23:178.

137. Khan MN, Li Y, Khan Z, Chen L, Liu J, Hu J, Wu H, Li Z. Nanoceria seed priming enhanced salt tolerance in rapeseed through modulating ROS homeostasis and a-amylase activities. J Nanobiotechnol. 2021;19(1):276.

138. Liu J, Li G, Chen L, Gu J, Wu H, Li Z. Cerium oxide nanoparticles improve cotton salt tolerance by enabling better ability to maintain cytosolic $\mathrm{K}^{+} / \mathrm{Na}^{+}$ratio. J Nanobiotechnol. 2021;19(1):153.

139. Jaberzadeh A, Payam M, Hamid R, Tohidi M, Hossein Z. Influence of bulk and nanoparticles titanium foliar application on some agronomic traits, seed gluten and starch contents of wheat subjected to water deficit stress. Notulae botanicae horti agrobotanici cluj-napoca. 2013:41:201-7.

140. Martinez-Fernandez D, Vítkova M, Bernal MP, Komarek M. Effects of nano-maghemite on trace element accumulation and drought response of Helianthus annuus L. in a contaminated mine soil. Water Air Soil Pollut. 2015;226(101):2365.

141. Aghdam MTB, Mohammadi H, Ghorbanpour M. Effects of nanoparticulate anatase titanium dioxide on physiological and biochemical performance of Linum usitatissimum (Linaceae) under well-watered and drought stress conditions. Braz J Bot. 2016:39:139-46.

142. Karami A, Sepehri A. Multiwalled carbon nanotubes and nitric oxide modulate the germination and early seedling growth of barley under drought and salinity. Agriculturae conspectus scinetificus. 2017:82:331-9.

143. Cao Z, Rossi L, Stowers C, Zhang W, Lombardini L, Ma X. The impact of cerium oxide nanoparticles on the physiology of soybean (Glycine max (L.) Merr.) under different soil moisture conditions. Environ Sci Pollut Res. 2018;25:930-9.

144. Mozafari AA, Havas F, Ghaderi N. Application of iron nanoparticles and salicylic acid in in vitro culture of strawberries (Fragaria $x$ ananassa Duch.) to cope with drought stress. Plant Cell Tissue Organ Cult. 2018;132:511-23.

145. Huang Q, Liu Q, Lin L, Li FJ, Han Y, Song ZG. Reduction of arsenic toxicity in two rice cultivar seedlings by different nanoparticles. Ecotoxicol Environ Saf. 2018;159:261-71.

146. Ali S, Rizwan M, Hussain A, Zia Ur Rehman M, Ali B, Yousaf B, Wijaya L, Alyemeni MN, Ahmad P. Silicon nanoparticles enhanced the growth and reduced the cadmium accumulation in grains of wheat (Triticum aestivum L.). Plant Physiol Biochem. 2019;140:1-8.

147. Wang X, Sun W, Ma X. Differential impacts of copper oxide nanoparticles and Copper (II) ions on the uptake and accumulation of arsenic in rice (Oryza sativa). Environ Pollut. 2019;252:967-73.

148. Zhang W, Long J, Li J, Zhang M, Xiao G, Ye X, Chang W, Zeng H. Impact of $\mathrm{ZnO}$ nanoparticles on $\mathrm{Cd}$ toxicity and bioaccumulation in rice (Oryza sativa L.). Environ Sci Pollut Res. 2019;26(22):23119-28.

149. Cui J, Li Y, Jin Q, Li F. Silica nanoparticles inhibit arsenic uptake into rice suspension cells via improving pectin synthesis and the mechanical force of the cell wall. Environ Sci Nano. 2020;7(1):162-71.

150. Wu X, Hu J, Wu F, Zhang X, Wang B, Yang Y, Wang X. Application of TiO2 nanoparticles to reduce bioaccumulation of arsenic in rice seedlings (Oryza sativa L): a mechanistic study. J Hazard Mater. 2020;405:124047. 
151. Jiang M, Dai S, Wang BQ, Xie ZM, Li JL, Wang LY, Li S, Tan YY, Tian B, Shu QY, Huang JZ. Gold nanoparticles synthesized using melatonin suppress cadmium uptake and alleviate its toxicity in rice. Environ Sci Nano. 2021;8:1042-56

152. Yan S, Wu F, Zhou S, Yang J, Tang X, Ye W. Zinc oxide nanoparticles alleviate the arsenic toxicity and decrease the accumulation of arsenic in rice (Oryza sativa L.). BMC Plant Biol. 2021;21:150.

153. Wang W, Vinocur B, Altman A. Plant responses to drought, salinity and extreme temperatures: towards genetic engineering for stress tolerance. Planta. 2003;218(1):1-14.

154. Ding Y, Shi Y, Yang S. Molecular regulation of plant responses to environmental temperatures. Mol Plant. 2020;13(4):544-64.

155. Aref Ml, El-Atta H, El-Obeid M, Ahmed Al, Khan PR, labal M. Effect of water stress on relative water and chlorophyll contents of Juniperus procera Hochst ex. Endlicher in Saudi Arabia. Life Sci J. 2013;10(4):681-5.

156. Mohammadi R, Amiri NM, Mantri L. Effect of $\mathrm{TiO}_{2}$ nanoparticles on oxidative damage and antioxidant defense systems in chickpea seedlings during cold stress. Russ J Plant Physiol. 2013;61:768-75.

157. Mohammadi H, Esmailpour M, Gheranpaye A. Effects of $\mathrm{TiO}_{2}$ nanoparticles and water-deficit stress on morpho-physiological characteristics of dragonhead (Dracocephalum moldavica L.) plants. Environ Toxicol Chem. 2014;33:2429-37.

158. Khodakovskaya MV, de Silva K, Biris AS, Dervishi E, Villagarcia H. Carbon nanotubes induce growth enhancement of tobacco cells. ACS Nano. 2012;6(3):2128-35.

159. Ganie SA, Molla KA, Henry RJ, Bhat KV, Mondal TK. Advances in understanding salt tolerance in rice. Theor Appl Genet. 2019;132(4):851-70.

160. Siddiqui $\mathrm{MH}$, Al-Whaibi $\mathrm{MH}$. Role of nano- $\mathrm{SiO}_{2}$ in germination of tomato (Lycopersicum esculentum seeds Mill.). Saudi J Biol Sci. 2014;21:13-7.

161. Torabian S, Zahedi M, Khoshgoftar AH. Effects of foliar spray of nanoparticles of $\mathrm{FeSO}_{4}$ on the growth and ion content of sunflower under saline condition. J Plant Nutr. 2017:40:615-23.

162. Aref IM, Khan PR, Khan S, El-Atta H, Ahmed Al, Iabal M. Modulation of antioxidant enzymes in Juniperus procera needles in relation to habitat environment and dieback incidence. Trees. 2016;30:1669-81.

163. Dimkpa CO, Bindraban PS, Fugice J, Agyin-Birikorang S, Singh U, Hellums D. Composite micronutrient nanoparticles and salts decrease drought stress in soybean. Agron Sustain Dev. 2017;37:5.

164. Rai PK, Lee SS, Zhang M, Tsang YF, Kim KH. Heavy metals in food crops: health risks, fate, mechanisms, and management. Environ Int. 2019;125:365-85.

165. Wang SH, Wang FY, Gao SC. Foliar application with nano-silicon alleviates $\mathrm{Cd}$ toxicity in rice seedlings. Environ Sci Pollut Res. 2015;22:2837-45.

166. Wang SH, Wang FY, Gao SC, Wang XG. Heavy metal accumulation in different rice cultivars as influenced by foliar application of nano-silicon. Water Air Soil Pollut. 2016;227:228.

167. Hussain A, Ali S, Rizwan M, Zia ur Rehman M, Javed MR, Imran M, Chatha SAS, Nazir R. Zinc oxide nanoparticles alter the wheat physiological response and reduce the cadmium uptake by plants. Environ Pollut. 2018:242:1518-26

168. Sun TY, Gottschalk F, Hungerbühler K, Nowack B. Comprehensive probabilistic modelling of environmental emissions of engineered nanomaterials. Environ Pollut. 2014;185:69-76.

169. Gardea-Torresdey JL, Rico CM, White JC. Trophic transfer, transformation, and impact of engineered nanomaterials in terrestrial environments. Environ Sci Technol. 2014;48:2526-40.

170. Dappe V, Dumez S, Bernard F, Hanoune B, Cuny D, Dumat C, Sobanska $\mathrm{S}$. The role of epicuticular waxes on foliar metal transfer and phytotoxicity in edible vegetables: case of Brassica oleracea species exposed to manufactured particles. Environ Sci Pollut Res. 2019;26:20092-106.

171. Song Y, Wang BQ, Qiu DY, Xie ZM, Dai S, Li C, Xu SL, Zheng YC, Li S, Jiang M. Melatonin enhances metallic oxide nanoparticle stress tolerance in rice via inducing tetrapyrrole biosynthesis and amino acid metabolism. Environ Sci Nano. 2021;8:2310-23.

172. Jiang M, Wang J, Rui M, Yang L, Shen J, Chu H, Song S, Chen Y. OsFTIP7 determines metallic oxide nanoparticles response and tolerance by regulating auxin biosynthesis in rice. J Hazard Mater. 2020;403:123946.

173. Rohr JR, Schotthoefer AM, Raffel TR, Carrick HJ, Halstead N, Hoverman JT, Johnson CM, Johnson LB, Lieske C, Piwoni MD, Schoff PK, Beasley VR.
Agrochemicals increase trematode infections in a declining amphibian species. Nature. 2008;455(7217):1235-9.

174. Li C, Li Y, Li Y, Fu G. Cultivation techniques and nutrient management strategies to improve productivity of rain-fed maize in semi-arid regions. Agric Water Manag. 2018;210:149-57.

175. Chhipa H. Nanofertilizers and nanopesticides for agriculture. Environ Chem Lett. 2017:15:15-22.

176. Godfray HCJ, Beddington JR, Crute IR, Haddad L, Lawrence D, Muir JF, Pretty J, Robinson S, Thomas SM, Toulmin C. Food security: the challenge of feeding 9 billion people. Science. 2010;327:812-8.

177. Shukla P, Chaurasia P, Younis K, Qadri OS, Faridi SA, Srivastava G. Nanotechnology in sustainable agriculture: studies from seed priming to post-harvest management. Nanotechnol Environ Eng. 2019:4:11.

178. Lateef A, Nazir R, Jamil N, Alam S, Shah R, Khan MN, Saleem M. Synthesis and characterization of zeolite based nano-composite: an environment friendly slow release fertilizer. Microporous Mesoporous Mater. 2016;232:174-83.

179. Wang Z, Yue L, Dhankher OP, Xing B. Nano-enabled improvements of growth and nutritional quality in food plants driven by rhizosphere processes. Environ Int. 2020:142:105831.

180. Servin AD, Michel HC, Viezcas JAH, Diaz BC, Videa JRP, Torresdey JLG. Synchrotron micro-XRF and micro-XANES confirmation of the uptake and translocation of $\mathrm{TiO}_{2}$ nanoparticles in cucumber (Cucumis sativus) plants. Environ Sci Technol. 2012;46:7637-43.

181. Zhao L, Peralta-Videa JR, Rico CM, Hernandez-Viezcas JA, Sun Y, Niu G, Servin A, Nunez JE, Duarte-Gardea M, Gardea-Torresdey JL. CeO and $\mathrm{ZnO}$ nanoparticles change the nutritional qualities of cucumber (Cucumis sativus). J Agric Food Chem. 2014;62(13):2752-9.

182. Trujillo-Reyes J, Majumdar S, Botez CE, Videa JRP, Gardea-Torresdey JL. Exposure studies of core-shell $\mathrm{Fe} / \mathrm{Fe}_{3} \mathrm{O}_{4}$ and $\mathrm{Cu} / \mathrm{CuO}$ NPs to lettuce (Lactuca sativa) plants: are they a potential physiological and nutritional hazard. J Hazard Mater. 2014;267:255-63.

183. Peralta-Videa JR, Hernandez-Viezcas JA, Zhao L, Diaz BC, Ge Y, Priester $J \mathrm{H}$, Holden PA, Gardea-Torresdey JL. Cerium dioxide and zinc oxide nanoparticles alter the nutritional value of soil cultivated soybean plants. Plant Physiol Biochem. 2014;80:128-35.

184. Sabir A, Yazar K, Sabir F, Kara Z, Yazici MA, Goksu N. Vine growth, yield, berry quality attributes and leaf nutrient content of grapevines as influenced by seaweed extract (Ascophyllum nodosum) and nanosize fertilizer pulverizations. Sci Hortic. 2014;175:1-8.

185. Feichtmeier NS, Walther P, Leopold K. Uptake, effects, and regeneration of barley plants exposed to gold nanoparticles. Environ Sci Pollut Res. 2015;22:8549-58.

186. Kale AP, Gawade SN. Studies on nanoparticle induced nutrient use eficiency of fertilizer and crop productivity. Green Chem. 2016;2:88-92.

187. Khan ST, Ahmad J, Ahamed M, Jousset A. Sub-lethal doses of widespread nanoparticles promote antifungal activity in Pseudomonas protegens CHAO. Sci Total Environ. 2018;627:658-62.

188. Panichikkal J, Thomas R, John JC, Radhakrishnan EK. Biogenic gold nanoparticle supplementation to plant beneficial Pseudomonas monteilii was found to enhance its plant probiotic effect. Curr Microbiol. 2019;76:503-6.

189. Shukla SK, Kumar R, Mishra RK, Pandey A, Pathak A, Zaidi MGH, Srivastava SK, Dikshit A. Prediction and validation of gold nanoparticles (GNPs) on plant growth promoting rhizobacteria (PGPR): a step toward development of nanobiofertilizers. Nanotechnol Rev. 2015;4:439-48.

190. Abdel-Aziz HMM, Hasaneen MNA, Omer AM. Nano chitosan-NPK fertilizer enhances the growth and productivity of wheat plants grown in sandy soil. Span J Agric Res. 2016;14:17.

191. Shalaby TA, Bayoumi Y, Abdalla N, Taha H, Alshaal T, Shehata S, Amer M, Domokos-Szabolcsy É, El-Ramady H. Nanoparticles, soils, plants and sustainable agriculture. Nanosci Food Agric. 2016;1:283-312.

192. Monreal CM, DeRosa M, Mallubhotla SC, Bindraban PS, Dimkpa C. Nanotechnologies for increasing the crop use efficiency of fertilizermicronutrients. Biol Fertil Soils. 2016;52:423-37.

193. Cai DQ, Wu ZY, Jiang J, Wu YJ, Feng HY, Brown IG, Chu PK, Yu ZL. Controlling nitrogen migration through micro-nano networks. Sci Rep. 2014:4:3665.

194. Liu RH, Kang YH, Pei L, Wan SQ, Liu SP, Liu SH. Use of a new controlledloss-fertilizer to reduce nitrogen losses during winter wheat cultivation 
in the Danjiangkou reservoir Area of China. Commun Soil Sci Plant Anal. 2016:47:1137-47.

195. Nuruzzaman M, Rahman MM, Liu YJ, Naidu R. Nanoencapsulation, nano-guard for pesticides: a new window for safe application. J Agric Food Chem. 2016;64:1447-83.

196. Haq IU, Ijaz S. Use of metallic nanoparticles and nanoformulations as nanofungicides for sustainable disease management in plants. Nanobiotechnol Bioformul. 2019;12:289-316.

197. Dwivedi S, Saquib Q, Al-Khedhairy AA, Musarrat J. Understanding the role of nanomaterials in agriculture. In: Microbial inoculants in sustainable agricultural productivity, vol. 17. 2016: 271-88.

198. De Jorge BC, Bisotto-de-Oliveira R, Pereira CN, Sant'Ana J. Novel nanoscale pheromone dispenser for more accurate evaluation of Grapholita molesta (Lepidoptera: Tortricidae) attract-and-kill strategies in the laboratory. Pest Manag Sci. 2017;73:1921-6.

199. Li ZZ, Chen JF, Liu F, Liu AQ, Wang Q, Sun HY, Wen LX. Study of UVshielding properties of novel porous hollow silica nanoparticle carriers for avermectin. Pest Manag Sci. 2007;63:241-6.

200. Heap I, Duke SO. Overview of glyphosate-resistant weeds worldwide. Pest Manag Sci. 2018;74(5):1040-9.

201. Shaner DL. Lessons learned from the history of herbicide resistance. Weed Sci. 2014;62:427-31.

202. Owen MDK. Diverse approaches to herbicide-resistant weed management. Weed Sci. 2016;64:57-584.

203. Pereira AES, Grillo R, Mello NFS, Rosa AH, Fraceto LF. Application of poly(epsilon-caprolactone) nanoparticles containing atrazine herbicide as an alternative technique to control weeds and reduce damage to the environment. J Hazard Mater. 2014;268:207-15.

204. Dashora A, Kanika S. Green synthesis of nanoparticles and their applications. Adv Sc Eng Med. 2018;10(6):523-41.

205. Hess FD. Herbicide effects on plant structure, physiology and biochemistry. In: Pesticide interactions in crop production, vol. 22. 2018.

206. Chinnamuthu CR, Boopathi PM. Nanotechnology and agroecosystem. Madras Agric J. 2009;96:17-31.
207. Satapanajaru T, Anurakpongsatorn P, Pengthamkeerati P, Boparai H. Remediation of atrazine-contaminated soil and water by nano zerovalent iron. Water Air Soil Pollut. 2008;192:349-59.

208. Gama-Lara SA, Pérez Mendoza MS, Vilchis-Nestor AR, Natividad R. Bionanotechnology: silver nanoparticles supported on bovine bone powder used as bactericide. Materials. 2020;13(2):462.

209. De Moraes ACP, Ribeiro LDS, de Camargo ER, Lacava PT. The potential of nanomaterials associated with plant growth-promoting bacteria in agriculture. 3 Biotech. 2021;11(7):318.

210. Imada K, Sakai S, Kajihara H, Tanaka S, Ito S. Magnesium oxide nanoparticles induce systemic resistance in tomato against bacterial wilt disease. Plant Pathol. 2016;65:551-60.

211. Shenashen M, Derbalah A, Hamza A, Mohamed A, El Safty S. Antifungal activity of fabricated mesoporous alumina nanoparticles against root rot disease of tomato caused by Fusarium oxysporium. Pest Manag Sci. 2017;73:1121-6.

212. Elmer W, De La Torre-Roche R, Pagano L, Majumdar S, Zuverza-Mena N, Dimkpa C, White JC. Effect of metalloid and metal oxide nanoparticles on fusarium wilt of watermelon. Plant Dis. 2018;102:1394-401.

213. Malandrakis AA, Kavroulakis N, Chrysikopoulos CV. Use of copper, silver and zinc nanoparticles against foliar and soil-borne plant pathogens. Sci Total Environ. 2019;670:292-9.

214. Cycoń M, Mrozik A, Piotrowska-Seget Z. Antibiotics in the soil environment-degradation and their impact on microbial activity and diversity. Front Microbiol. 2019;10:338.

215. Frenk S, Ben-Moshe T, Dror I, Berkowitz B, Minz D. Effect of metal oxide nanoparticles on microbial community structure and function in two different soil types. PLoS ONE. 2013;8:e84441.

\section{Publisher's Note}

Springer Nature remains neutral with regard to jurisdictional claims in published maps and institutional affiliations.
Ready to submit your research? Choose BMC and benefit from:

- fast, convenient online submission

- thorough peer review by experienced researchers in your field

- rapid publication on acceptance

- support for research data, including large and complex data types

- gold Open Access which fosters wider collaboration and increased citations

- maximum visibility for your research: over $100 \mathrm{M}$ website views per year

At BMC, research is always in progress.

Learn more biomedcentral.com/submissions 